\title{
Nauplius
}

The Journal of The

Brazilian Crustacean Society

This article is part of the tribute offered

by the Brazilian Crustacean Society

in memoriam of Michael Türkay for his

e-ISSN 2358-2936

www.scielo.br/nau

www.crustacea.org.br

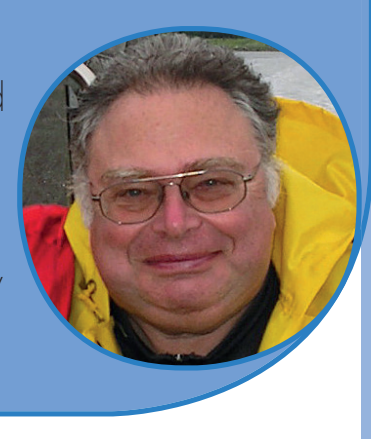

Original Article

\section{An annotated checklist of marine caridean and stenopodidean shrimps (Malacostraca: Decapoda) of the Caribbean coast of Panama}

\author{
Sammy De Grave ${ }^{1}$ and Arthur Anker ${ }^{2,3}$ \\ 1 Oxford University Museum of Natural History, Parks Road, Oxford, OX1 3PW, \\ United Kingdom. \\ SDG E-mail: sammy.degrave@oum.ox.ac.uk \\ 2 Programa de Capacitação Institucional, Museu Paraense Emílio Goeldi, \\ Campus de Pesquisa. Avenida Perimetral, 1901, Terra Firme. 66077-830 Belém, \\ Pará, Brazil. \\ 3 Current affiliation: Universidade Federal de Goiás, Campus Samambaia, Instituto de \\ Ciências Biológicas - ICB 5. Av. Esperança, s/n. 74690-900 Goiânia, Goiás, Brazil. \\ AA E-mail: arthuranker7@gmail.com \\ ZOOBANK http://zoobank.org/urn:lsid:zoobank.org:pub:2C57A452-3104-4AC0- \\ 8614-179СBC32362C
}

\section{AbSTRACt}

A checklist of caridean and stenopodidean shrimps of the Caribbean coast of Panama is presented, based on material collected during two local workshops $(2005,2008)$ as well as extensive sampling during 2006-2010. This material is augmented by an annotated list of previously recorded species, amounting to a total of 157 species, including 20 new records. Doubtful records are discussed. The current checklist is however considered relatively incomplete

CORRESPONDING AUTHOR Sammy De Grave

sammy.degrave@oum.ox.ac.uk

SUBMITTED 16 November 2016 ACCEPTED 29 December 2016 PUBLISHED 5 June 2017

Guest Editor

Célio Magalhães

DOI 10.1590/2358-2936e2017015 as older records could not always be verified and more taxa remain to be described. Despite the deficiencies of the present list, the Caribbean coastline of Panama is clearly one of the most species rich areas in the entire Atlantic Ocean for caridean shrimps.

\section{KEY WORDS}

Caridea, Central America, faunal list, new records, Neotropical region, Stenopodidea. 


\section{INTRODUCTION}

Although a few early records of shrimps exist for Caribbean Panama (e.g. Kingsley, 1879; Coutière, 1909), large scale decapod faunal recording started with the work of Lawrence G. (Larry) Abele, who commenced working on the local fauna in 1968 and sampled a total of 119 stations along both the Caribbean and Pacific coastline over a 15 month period (see Abele, 1972a). In the same year, a significant oil spillage near the Smithsonian Tropical Research Institute (STRI)'s research centre at Punta Galeta, led to a three-year long study of the local habitats and communities, which started in 1970 and resulted in an extensive faunal list (see Birkeland et al., 1976). These faunal lists enabled some ecological work (e.g. Heck, 1977 on sea grass communities) and culminated in a checklist of the invertebrates of Punta Galeta (Cubit and Williams, 1983).

From this, it is immediately obvious that the history of faunal recording in Panama is closely linked to the history of STRI (detailed in Robertson et al., 2009), which has operated several research stations along the Caribbean coast of Panama. The Punta Galeta laboratory was the first to be opened in 1964 and provided a nucleus for early records. Marine research in the San Blas archipelago followed in 1970, increasing with the opening of a laboratory in 1977, which continued for 20 years. In 2003, a state-of-the-art research laboratory (Bocas del Toro Research Station or BRS) was opened on Isla Colón in the Bocas del Toro Archipelago, with the majority of shrimp records for Caribbean Panama, detailed in the present list originating in that area.

Since its opening, the BRS station has organised several international invertebrate taxonomy workshops, as well as a series of taxonomic training workshops (Collin, 2005), both of which contributed significantly to the present checklist. Given the presence of wellequipped laboratories, numerous ecological and evolutionary studies have been carried out in the region. As a result many faunistic records are hidden in nontaxonomic publications, in which often working names have been used rather than updated nomenclature. In addition, a number of photographs or personal communications have appeared in recent years, based on species not formally recorded from the area.

The present checklist compiles this range of disparate sources using up-to-date nomenclature and classification, as well as reporting on unpublished collections largely obtained during two workshops $(2005,2008)$ at the BRS station, and additional fieldwork conducted in 2015. Nomenclature and classification generally follows De Grave and Fransen (2011), updated by De Grave et al. (2014) for hippolytoid families and De Grave et al. (2015) for palaemonoid families. For literature records, the area from which the species was recorded is given, unless this was not stated in the original record, in which case "Caribbean Panama" is used. Several taxa, especially Alpheidae, were previously recorded under various codes, e.g. Synalpheus bousfieldi "A" in Morrison et al. (2004); these have all herein been linked to formally described taxa to facilitate future studies. Questionable records are indicated by (?). Material examined for the present work is largely deposited in the Zoological Collections of the Oxford University Museum of Natural History, Oxford, U.K. (OUMNH. ZC) with additional samples in Museu de Zoologia da Universidade de São Paulo, São Paulo, Brazil (MZUSP) and the Florida Museum of Natural History, University of Florida, Gainesville, USA (FLMNH UF).

\section{Systematics}

\section{Infraorder Caridea Dana, 1852}

\section{Family Alpheidae Rafinesque, 1815}

\section{Alpheopsis labis Chace, 1972}

Previous records. Anker et al., 2006: 2510 [Isla Grande].

Remarks. Sparsely recorded in the tropical western Atlantic, mainly in the Caribbean Sea, with an unconfirmed record from Brazil; in and under coral rubble, less than $10 \mathrm{~m}$. The species may need a thorough taxonomic revision (Anker et al., 2016).

\section{Alpheopsis trigona (Rathbun, 1901)}

Previous records. Williams et al., 2001: 376 [San Blas, as A. trigonus].

Remarks. Sparsely recorded in the western Atlantic, from Bermuda southwards to Panama and Bahia, Brazil; in coral rubble, in depths of $0-46 \mathrm{~m}$; a species complex being revised at the moment (Anker, in prep.). 


\section{Alpheus amarillo Anker, 2012}

Previous records. Matthews and Anker, 2009: 277 [Bocas del Toro, Isla Grande; as A. cf. armillatus C]; Anker, 2012: 42 [Portobelo Bay; San Blas].

Remarks. Currently known from several localities in the Caribbean Sea, Florida and southern Gulf of Mexico (De Grave et al., 2017); typically under rocks and coral rubble on sandy patches between coral stands, in depths of 2-30 m.

\section{Alpheus amblyonyx Chace, 1972}

Previous records. Williams et al., 2001: 377 [Caribbean Panama].

Material examined. Bocas del Toro. 1 spec., Isla Colón, Punta Caracol, sand, coral rubble, sea grass, in rubble, 0.5-2 m, leg. A. Anker et al., 27.04.2015, MZUSP 33921. Isla Grande. 1 spec., western point, leg. A. Anker et al., 09.12.2006, OUMNH.ZC.2011-03070; 1 spec., same collection data, OUMNH.ZC.201103-072; 1 spec., same collection location, leg. A. Anker et al., 04.09.2006, OUMNH.ZC.2011-03-071.

Remarks. Throughout the Caribbean Sea and Gulf of Mexico southwards to Trindade Island off Espírito Santo, Brazil (Soledade and Almeida, 2013); usually on coral reefs and sea grass beds with rubble, between 0 and $25 \mathrm{~m}$. Possibly more than one species involved, records from much deeper water $(145 \mathrm{~m})$ off northeastern USA are highly questionable (Anker et al., 2016).

\section{Alpheus angulosus McClure, 2002}

Previous records. Matthews and Anker, 2009: 277 [Bocas del Toro, Isla Grande; as A. cf. armillatus A3]; Hernáez et al., 2010: 694 [Bocas del Toro]; Anker, 2012: 31 [Bocas del Toro; Isla Grande].

Material examined. Bocas del Toro. $1 \mathrm{spec}$. Isla Colón, Boca del Drago, 09²4.764’N 082¹9.868'W, under rocks, 0.5-1 m, leg. A. Anker, 04.08.2008, OUMNH.ZC.2008-14-100; 1 spec., same collection data, OUMNH.ZC.2008-14-095; 4 spec., Isla Colón,
Puss Head Point, $09^{\circ} 21.802^{\prime} \mathrm{N} 082^{\circ} 14.333^{\prime} \mathrm{W}$, under rocks, 1-2 m, leg. S. De Grave, 08.08.2008, OUMNH. ZC.2008-14-082.

Remarks. Widespread in the western Atlantic, ranging from North Carolina southwards to Rio Grande do Sul, Brazil, including Caribbean Sea and Gulf of Mexico (Anker, 2012); typically under rocks on fine sand, also in oyster reefs and sea grass beds; intertidal to about $5 \mathrm{~m}$.

\section{Alpheus armatus Rathbun, 1901}

Previous records. (?) Abele, 1976: 273 [around Colón]; (?) Cubit and Williams, 1983: 24 [Galeta Point]; Hurt et al., 2013: 4536 [Isla Grande].

Material examined. Bocas del Toro. 1 spec., Isla Colón, Boca del Drago, in rock crevice, with Bartholomea annulata (Le Sueur, 1817), leg. A. Anker, 02.05.2015, MZUSP 33537.

Remarks. Well-known species, with records from Florida, throughout Caribbean Sea and southern Gulf of Mexico (Hurt et al., 2013); associated with the cork-screw sea-anemone B. annulata, typically in shallow water (1-10 m). Both earlier records from Panama, i.e. prior to the description of several closely related species (Knowlton and Keller, 1983; 1985), need confirmation.

\section{Alpheus armillatus H. Milne Edwards, 1837}

Previous records. (?) Abele, 1976: 273 [around Colón]; (?) Birkeland et al., 1976: 135 [Galeta reef]; (?) Heck, 1977: 234 [around Galeta Island]; (?) Heck and Wetstone, 1977: 200 [around Galeta]; (?) Cubit and Williams, 1983: 24 [Galeta Point]; (?) Abele and Kim, 1989: 14 [Gatun Locks]; Matthews and Anker, 2009: 277 [Bocas del Toro, Isla Grande; as A. cf. armillatus A]; Anker, 2012: 9 [Isla Grande, Bocas del Toro].

Material examined. Bocas del Toro. 1 spec., Isla Colón, Boca del Drago, 09²4.924’N 082¹9.824’W, in rubble in sea grass bed, leg. S. De Grave, 10.08.2008, OUMNH.ZC.2008-14-117; 1 spec., Isla Bastimentos, 
Cayo Coral (Coral Cay), 09¹4.502’N 082 ${ }^{\circ} 08.288^{\prime} \mathrm{W}$, under rocks and coral rubble, $1 \mathrm{~m}$, leg. A. Anker, 11.08.2008, OUMNH.ZC.2008-14-122.

Remarks. Known with certainty from several localities in the Caribbean Sea, southern Florida and the Gulf of Mexico (Anker, 2012); records from further north (eastern USA) or south (Brazil) belong to either $A$. angulosus or one of the new species described in Anker (2012); in mixed sand-rubble habitats, 0-10 m. The true identity of older Panamanian records cannot be resolved as they may refer to any of the Caribbean species of the A. armillatus complex (see Anker, 2012).

\section{Alpheus bahamensis Rankin, 1898}

Previous records. Abele, 1976: 273 [around Colón]; Birkeland et al., 1976: 135 [Galeta reef]; Cubit and Williams, 1983: 24 [Galeta Point].

Material examined. Bocas del Toro. 1 spec., Isla Colón, Puss Head Point, $09^{\circ} 21.802^{\prime} N$ 082 $14.333^{\prime}$ W, in rubble, 1-2 m, leg. S. De Grave and A. Anker, 08.08.2008, OUMNH.ZC.2008-14-080; 3 spec., same collection data, OUMNH.ZC.2008-14-079; 1 spec., Isla Colón, between Puss Head and Playa Bluff, leg. A. Anker et al., 13.11.2006, OUMNH.ZC.2010-01-030. Isla Grande. 2 spec., western point, leg. A. Anker et al., 21.04.2006, OUMNH.ZC.2011-03-059.

Remarks. Tropical western Atlantic, from Bermuda southwards to Tobago (Felder et al., 2009), including southern Gulf of Mexico, most common on coral reefs, in crevices of dead corals, $0-5 \mathrm{~m}$.

\section{Alpheus bouvieri A. Milne-Edwards, 1878}

Previous records. Abele, 1976: 273 [around Colón]; Knowlton and Weigt, 1998: 2258 [Caribbean Panama]; Williams et al., 2001: 377 [Caribbean Panama]; Hurt et al., 2009: 516 [Caribbean coast]; Anker et al., 2009: 5 [Bocas del Toro].

Remarks. Amphi-Atlantic species, in the western Atlantic recorded from Bermuda southwards to Rio Grande do Sul, Brazil, including much of the Caribbean Sea and southern Gulf of Mexico (Anker et al., 2009;
Soledade and Almeida, 2013); usually in rock or dead coral crevices, intertidal to about $5 \mathrm{~m}$.

\section{Alpheus carlae Anker, 2012}

Previous records. Matthews and Anker, 2009: 277 [Caribbean Panama; as A. cf. armillatus F]; Anker, 2012: 61 [Bocas del Toro].

Remarks. Sparsely recorded from the Florida Keys southwards to the Caribbean Sea and São Paulo, Brazil (Almeida et al., 2015); in a wide range of habitats (rocky shores, mangroves, sea grass beds), typically under rocks in the intertidal or shallow subtidal (less than $5 \mathrm{~m})$.

\section{Alpheus chacei Carvacho, 1979}

Previous records. Knowlton and Weigt, 1998: 2258 [Caribbean Panama]; Williams et al., 2001: 377 [Caribbean Panama].

Material examined. Bocas del Toro.1 spec., Laguna Chiriqui, off Punta Robalo, 20-50m, by dredge, leg. J. Jara et al., 14.10.2007, OUMNH.ZC.2016-01-031; same collection data, OUMNH.ZC.2016-01-032.

Remarks. Currently known from Guadeloupe, Cuba, Panama and several Brazilian states (Pará to São Paulo) (Soledade and Almeida, 2013); restricted to estuaries and mangroves, in burrows in soft mud, intertidal to $5 \mathrm{~m}$.

\section{Alpheus christofferseni Anker, Hurt and Knowlton, 2007}

Previous records. Anker et al., 2007a: 4 [Bocas del Toro].

Material examined. Bocas del Toro. 1 spec., Isla Carenero, $09^{\circ} 20.675^{\prime} \mathrm{N} 082^{\circ} 13.762^{\prime} \mathrm{W}$, in burrow, 0.5 m, leg. A. Anker, 06.08.2008, OUMNH.ZC.2008-14093; 1 spec., Isla Colón, Boca del Drago, sea grass flat, in burrow, suction pump, $0.2-1.5 \mathrm{~m}$, leg. A. Anker et al., 01.05.2015, MZUSP 33938.

Remarks. Currently known only from Atol das Rocas, Brazil, and Caribbean coast of Panama (Soledade and 
Almeida, 2013); in burrows on intertidal or shallow sea grass flats $(0-1 \mathrm{~m})$, associated with echiurans.

\section{Alpheus cristulifrons Rathbun, 1900}

Previous records. Abele, 1976: 272 [around Colón]; Birkeland et al., 1976: 135 [Galeta reef]; Cubit and Williams, 1983: 24 [Galeta Point]; Knowlton et al., 1993: 1630 [Caribbean Panama]; Knowlton and Weigt, 1998: 2258 [Caribbean Panama]; Williams et al., 2001: 377 [Caribbean Panama]; Anker et al., 2008a: 549 [Bocas del Toro; Isla Grande].

Material examined. Bocas del Toro. 1 spec., Isla Colón, Puss Head Point, 09²1.802’N 082¹4.333’W, in rubble, 1-2 m, leg. A. Anker and S. De Grave, 09.08.2008, OUMNH.ZC.2008-14-089, 1 spec., same collection data, OUMNH.ZC. 2008-14-084.

Remarks. Widely distributed in the tropical western Atlantic, from the northern Gulf of Mexico and Florida southwards to Rio de Janeiro, Brazil (Soledade and Almeida, 2013); usually dwelling deep in rubble crevices, in depths of $0-15 \mathrm{~m}$.

\section{Alpheus estuariensis Christoffersen, 1984}

Previous records. Knowlton and Weigt, 1998: 2258 [Caribbean Panama]; Williams et al., 2001: 377 [Caribbean Panama].

Material examined. Bocas del Toro. 1 spec., Isla Colón, Playa de las Estrellas, 09²4.297’ N $082^{\circ} 19.490^{\prime} \mathrm{W}$, in burrow in muddy sand close to mangrove creek, suction pump, less than $0.5 \mathrm{~m}$, leg. A. Anker, 09.08.2008, OUMNH.ZC.2008-14-083.

Remarks. Distributed in the western Atlantic from Florida to Santa Catarina, Brazil, with few records in the Caribbean Sea (Soledade and Almeida, 2013); in burrows in estuaries and mangroves, intertidal to about $5 \mathrm{~m}$.

\section{Alpheus floridanus Kingsley, 1878}

Previous records. Heck, 1977: 338 [around Galeta Island]; Heck, 1979: 198 [Caribbean Panama]; Cubit and Williams, 1983: 24 [Galeta Point]; Knowlton and Weigt, 1998: 2258 [Caribbean Panama]; Williams et al., 2001: 377 [Caribbean Panama]; Bracken-Grissom and Felder, 2014: 453 [Bocas del Toro].

Material examined. Bocas del Toro. 1 spec., Isla Carenero, near Buccaneer, shallow sea grass beds, suction pump, 0.5-1 m, leg. A. Anker, 02.05.2007, OUMNH.ZC.2010-01-102; 1 spec., same location, leg. A. Anker et al., 14.11.2006, OUMNH.ZC.2010-01105; 1 spec., same collection data, OUMNH.ZC.201001-103; 1 spec., same collection data, OUMNH. ZC.2010-01-104; 1 spec., same collection data, OUMNH.ZC.2010-01-006; 1 spec., same collection data, OUMNH.ZC.2010-01-123.

Remarks. Widely distributed in the tropical western Atlantic, from Florida southwards to Rio de Janeiro, Brazil, and throughout Caribbean Sea; in shallow sand flats or sea grass beds, extending down to about $55 \mathrm{~m}$. Some records prior to the revision of the $A$. floridanus species complex (Bracken-Grissom and Felder, 2014) may refer to closely related species, e.g. Alpheus roblesi Bracken-Grissom and Felder, 2014 or Alpheus platycheirus Boone, 1927 (see below).

\section{Alpheus formosus Gibbes, 1850}

Previous records. (?) Abele, 1976: 272 [around Colón]; (?) Birkeland et al., 1976: 136 [Galeta reef]; (?) Heck, 1979: 200 [Caribbean Panama]; (?) Cubit and Williams, 1983: 24 [Galeta Point]; (?) Heck, 1977: 338 [area around Galeta island]; Knowlton and Mills, 1992: 2 [Caribbean Panama]; Knowlton and Weigt, 1998: 2258 [Caribbean Panama, as A.formosus sp. a]; Williams et al., 2001: 377 [Caribbean Panama, as A. formosus A]; Anker et al., 2008b: 5 [Bocas del Toro; Isla Grande].

Remarks. Common and conspicuous species widely distributed in the western Atlantic, from North Carolina southwards to São Paulo and Trindade Island, Brazil, including most of the Caribbean Sea and Gulf of Mexico (Anker et al., 2008b; 2016); typically in reef and nearby habitats, especially amongst rubble, in depth of 0-40 m. Older records may refer to the relatively recently described Alpheus paraformosus 
Anker, Hurt and Knowlton, 2008, which also occurs in Panama (see below).

\section{Alpheus heterochaelis Say, 1818}

Previous records. (?) Kingsley, 1879: 58 [Panama]; (?) Heck, 1977: 338 [around Galeta Island]; (?) Heck, 1979: 199 [Caribbean Panama]; (?) Abele and Kim, 1989: 15 [Gatun Locks].

Remarks. The presence of $A$. heterochaelis in Panama is highly questionable and all herein listed records are considered as doubtful. Most likely, these records refer to one or both recently described Atlantic species which are morphologically similar to A. heterochaelis: Alpheus buckupi Almeida, Terossi, Araújo-Silva and Mantelatto, 2013 (known from the Lesser Antilles southwards to São Paulo, Brazil, as well as São Tomé in the eastern Atlantic, see Pachelle et al., 2016) and/ or Alpheus petronioi Almeida, Terossi and Mantelatto, 2014 (known from Colombia and Venezuela to São Paulo, Brazil, see Almeida et al., 2014).

\section{Alpheus immaculatus Knowlton and Keller, 1983}

Previous records. Hurt et al., 2013: 4536 [Isla Grande].

Remarks. Recorded from several scattered locations in the Caribbean Sea and the southern Gulf of Mexico (De Grave et al., 2017); always associated with the corkscrew sea-anemone B. annulata at depths of 8-17 m.

\section{Alpheus intrinsecus Spence Bate, 1888}

Material examined. Bocas del Toro. 1 spec., Isla Colón, Boca del Drago, on sand under rocks, less than $1 \mathrm{~m}$, leg. A. Anker et al., 29.04.2007, OUMNH. ZC.2011-03-013; 1 spec., Isla Carenero, northern side, $09^{\circ} 20.675^{\prime} \mathrm{N} 082^{\circ} 13.762^{\prime} \mathrm{W}$, in crevice of sunken tree trunk, 0.5 m, leg. B. Martínez-Guerrero, 06.08.2008, OUMNH.ZC.2008-14-098.

Remarks. Amphi-Atlantic taxon, in the western Atlantic distributed from Puerto Rico southwards to Santa Catarina, Brazil (Soledade and Almeida, 2013), appears to be much more common in Brazil; usually found under rocks in sandy-rocky habitats, $0-30 \mathrm{~m}$. The specimens from Bocas del Toro represent the first record of the species for Panama.

\section{Alpheus lancirostris Rankin, 1900}

Previous records. Matthews and Anker, 2009: 277 [San Blas Islands; as A. cf. armillatus J]; Anker, 2012: 18 [San Blas Islands].

Remarks. Sparsely recorded from Bermuda southwards to Venezuela and Panama (Anker, 2012); typically encountered under large rocks or in rubble, close to coral reefs, $0-2 \mathrm{~m}$.

\section{Alpheus malleator Dana, 1852}

Previous records. Abele, 1976: 273 [around Colón]; Knowlton and Weigt, 1998: 2258 [Caribbean Panama]; Williams et al., 2001: 377 [Caribbean Panama]; Hurt et al., 2009: 516 [Caribbean Panama]; Anker and Pachelle, 2013: 415 [Isla Grande].

Remarks. Amphi-Atlantic taxon, in the western Atlantic known based on a few records from Florida southwards to São Paulo, Brazil, including the Caribbean Sea and southern Gulf of Mexico (Soledade and Almeida, 2013); lives deep in cavities in exposed rocky and coral reef substrates, $0-5 \mathrm{~m}$.

\section{Alpheus mathewsae Anker, 2012}

Previous records. Matthews and Anker, 2009: 277 [Bocas del Toro; Isla Grande; as A. cf. armillatus H1]; Anker, 2012: 68 [Isla Grande; Bocas del Toro].

Material examined. Bocas del Toro. 1 spec., Isla Bastimentos, southern shore near Bastimentos village, fine sand and mud near mangroves, under large pieces of rubble, 0-1 m, leg. A. Anker et al., 29.04.2015, MZUSP 34045.

Remarks. Sparsely recorded from Florida southwards to Panama (Anker, 2012); typically found under rocks and coral rubble on fine sand or silt, in sheltered locations, 0-2 m 


\section{Alpheus nuttingi (Schmitt, 1924)}

Previous records. Birkeland et al., 1976: 136 [Galeta reef]; Cubit and Williams, 1983: 24 [Galeta Point]; Knowlton and Mills, 1992: 2 [Caribbean Panama]; Knowlton et al., 1993: 1630 [Caribbean Panama]; Knowlton and Weigt, 1998: 2258 [Caribbean Panama]; Williams et al., 2001: 377 [Caribbean Panama]; Anker et al., 2007b: 44 [Bocas del Toro; Colón]; Hurt et al., 2009: 516 [Caribbean Panama].

Material examined. Bocas del Toro. 2 spec., Isla Colón, between STRI and Playa Bluff, sand flat with rubble, 0.3-1 m, leg. A. Anker et al., 26.04.2015, MZUSP 34036. Isla Grande. 1 spec., western point, leg. A. Anker et al., 23.04.2006, OUMNH.ZC.201001-020. Portobelo. 2 spec., coral rubble, leg. A. Anker and A. Baeza, 04.08.2007, OUMNH.ZC.2009-18-044.

Remarks. Common western Atlantic species, widely distributed from Florida southwards to Santa Catarina, Brazil, including much of the Caribbean Sea and Gulf of Mexico (Soledade and Almeida, 2013); typically on sandy bottoms under rocks and rubble or in crevices of dead corals, $0-5 \mathrm{~m}$.

\section{Alpheus packardii Kingsley, 1880}

Previous records. (?) Heck, 1977: 338 [around Galeta Island, as Alpheus normanni Kingsley, 1878]; (?) Birkeland et al., 1976: 136 [Galeta reef, as A. normanni]; (?) Heck, 1979: 199 [Caribbean Panama, as A.normanni]; (?) Cubit and Williams, 1983:24 [Galeta Point, as A.normanni]; (?) Knowlton and Weigt, 1998: 2258 [Caribbean Panama, as A. normanni]; (?) Williams et al., 2001: 377 [Caribbean Panama, as A. normanni A, B, C].

Material examined. Bocas del Toro. 1 spec., Isla Colón, Boca del Drago, $09^{\circ} 24.764^{\prime} \mathrm{N} 082^{\circ} 19.868^{\prime} \mathrm{W}$, under rocks near sea grass, $0.5-1 \mathrm{~m}$, leg. A. Anker, 04.08.2008, OUMNH.ZC.2008-14-108; many spec., Isla Colón, Boca del Drago, 09²4.764'N 082²19.868’ W, intertidal and shallow subtidal near sea grass bed, at night, leg. A. Anker, 05.08.2008, OUMNH.ZC.200814-081; 1 spec., Isla Colón, off STRI station pier, $09^{\circ} 14.983^{\prime} \mathrm{N} 082^{\circ} 08.239^{\prime} \mathrm{W}$, dredge, $0.5 \mathrm{~m}$, leg. S. De Grave, 09.08.2005, OUMNH.ZC.2005-10-084; 1 spec., Isla Colón, off STRI station pier $09^{\circ} 14.983^{\prime} \mathrm{N}$ $082^{\circ} 08.239^{\prime} \mathrm{W}$, sea grass bed, sledge at night, S. De Grave, 04.08.2008, OUMNH.ZC.2008-14-096, 2 spec., same location, leg. S. De Grave, 07.08.2005, OUMNH. ZC.2005-10-097.

Remarks. Alpheus packardii is part of the still unresolved transisthmian $A$. normanni species complex, which includes at least five (pseudo)cryptic taxa (Williams et al., 2001; Anker, in prep.). Therefore, the true identity of the material recorded under this name from the Caribbean coast of Panama is currently unknown, but it is certain that more than one species from this complex is present in the area (Anker, in prep.).

\section{Alpheus paracrinitus Miers, 1881}

Previous records. (?) Birkeland et al., 1976: 136 [Galeta reef]; (?) Cubit and Williams, 1983: 24 [Galeta Point]; (?) Knowlton and Mills, 1992: 2 [Caribbean Panama]; (?) Knowlton et al., 1993: 1630 [Caribbean Panama, as A. paracrinitus sp. a and b]; (?) Knowlton and Weigt, 1998: 2258 [Caribbean Panama, as $A$. paracrinitus sp. a and b]; (?) Williams et al., 2001: 377 [Caribbean Panama, as A. paracrinitus "no spot A", "no spot B" and "spot"].

Material examined. Bocas del Toro. 1 spec., Isla Colón, Boca del Drago, 09²4.924’N 082¹9.834’W, sea grass bed, leg. S. De Grave, 04.08.2008, OUMNH. ZC.2008-14-107; 3 spec., same location, in rubble among sea grass, leg. S. De Grave, 10.08.2008, OUMNH.ZC.2008-14-118; 1 spec., Isla Colón, Boca del Drago, $09^{\circ} 24.764^{\prime} \mathrm{N}$ 082 $19.868^{\prime} \mathrm{W}$, under rocks, 0.5-1 m, leg. A. Anker, 04.08.2008, OUMNH. ZC.2008-14-105; 1 spec., same collection data, OUMNH.ZC.2008-14-106.

Remarks. Alpheus paracrinitus is an unresolved pantropical species complex, with at least two taxa present along the Caribbean coast of Panama, substantiated by differences in their colour patterns as well as molecular data (Williams et al., 2001). 


\section{Alpheus paraformosus Anker, Hurt and Knowlton, 2008}

Previous records. Knowlton and Weigt, 1998: 2258 [Caribbean Panama, as A. formosus sp. a]; Williams et al., 2001: 377 [Caribbean Panama, as A.formosus B]; Anker et al., 2008b: 12 [Bocas del Toro; Isla Grande; San Blas Islands]; Hurt et al., 2009: 516 [Caribbean coast].

Material examined. Bocas del Toro. $1 \mathrm{spec}$. , Isla Solarte, Hospital Point, $09^{\circ} 19.996^{\prime} \mathrm{N} 082^{\circ} 13.161^{\prime} \mathrm{W}$, in shallow rubble, leg. S. De Grave, 04.08.2008, OUMNH. ZC.2008-14-028; 1 spec., Isla Colón, Puss Head Point, $09^{\circ} 21.802^{\prime} \mathrm{N} 082^{\circ} 14.333^{\prime} \mathrm{W}$, in coral rubble, $1-2 \mathrm{~m}$, leg. S. De Grave, 09.08.2008, OUMNH.ZC. 2008-14-087; many spec., Isla Bastimentos, Cayo Coral, in empty conch shells, leg. C. Tavares, 06.08.2008, OUMNH. ZC.2008-14-135.

Remarks. Presently known from a few scattered Caribbean localities, including St. Martin, Panama (Bocas del Toro, Isla Grande), and Honduras (Bay Islands), as well as the southern Gulf of Mexico (Alacranes Reef off Yucatan) (Anker et al., 2008b; Duarte et al., 2014); typically dwelling in coral rubble crevices in shallow water, 0-3 m. Anker et al. (2008b) listed San Blas Islands as an additional Panamanian locality for A. paraformosus, however, without having deposited a voucher specimen.

\section{Alpheus peasei (Armstrong, 1940)}

Previous records. Abele, 1976: 273 [around Colón]; Birkeland et al., 1976: 136 [Galeta reef]; Cubit and Williams, 1983: 24 [Galeta Point]; Williams et al., 2001: 377 [Caribbean Panama].

Material examined. Bocas del Toro. 1 spec., Isla Colón, Puss Head Point, 09²1.802’N 082¹4.333’W, in coral rubble, $1-2 \mathrm{~m}$, leg. S. De Grave and A. Anker, 09.08.2008, OUMNH.ZC.2008-14-090; 1 spec., same collection data, OUMNH.ZC.2008-14-086; 2 spec., Isla Colón, between Big Creek and Playa Bluff, leg. A. Anker et al., 18.10.2005, OUMNH.ZC.2011-03156; 1 spec., Isla Colón, Boca del Drago, 09²4.924’N $082^{\circ} 19.824^{\prime} \mathrm{W}$, in coral rubble among sea grass, leg. S. De Grave, 10.08.2008, OUMNH.ZC.2008-14-114.

Remarks. Widely distributed from Bermuda southwards to Bahia and Trindade and Martin Vaz Archipelago, Brazil, including most of the Caribbean Sea and Gulf of Mexico (Soledade and Almeida, 2013); occurs in a variety of hard-bottom habitats, typically on coral reefs and in coralline algae, $1-30 \mathrm{~m}$, but most common in very shallow water (less than $5 \mathrm{~m}$ ).

\section{Alpheus platycheirus Boone, 1927}

Material examined. Bocas del Toro. 1 spec., Isla Bastimentos, near Bastimentos village, shallow muddy flat, suction pump, 0.2-1 m, leg. A. Anker et al., 18.11.2006, OUMNH.ZC.2011-03-157; 1 spec., same collection data, OUMNH.ZC.2010-01-004; same collection data, OUMNH.ZC.2012-07-001; 1 spec., same collection data, OUMNH.ZC.2010-01-007; 1 spec., same collection data, OUMNH.ZC.2010-01005; 1 spec., Isla Colón, Boca del Drago, 0.2-1.5 m, 02.05.2015, MZUSP 34283.

Remarks. Sparsely recorded from the Gulf of Mexico and the Caribbean as well as Rio de Janeiro (Brazil) (Chace, 1972), now Panama; on muddy bottoms, usually between $12-122 \mathrm{~m}$, although the present specimens were from much shallower water.

\section{Alpheus polystictus Knowlton and Keller, 1985}

Previous records. Knowlton and Keller, 1985: 897 [Caribbean Panama]; Hurt et al., 2013: 4536 [Isla Grande].

Material examined. Bocas del Toro. 1 spec., Isla Colón, Boca del Drago, in rock crevice, with B. annulata, $\sim 1 \mathrm{~m}$, leg. A. Anker, 02.05.2015, MZUSP 33493.

Remarks. Sparsely recorded from southern Florida southwards to Venezuela and Panama, but not (yet) recorded from the Gulf of Mexico (Hurt et al., 2013); obligate associate of the cork-screw sea-anemone, $B$. annulata in shallow water, $1-12 \mathrm{~m}$. 


\section{Alpheus punctatus Anker, 2012}

(Fig. 1A)

Previous records. Anker, 2012: 50 [Bocas del Toro].

Material examined. Bocas del Toro. 1 spec., Isla Colón, Punta Caracol, sand, coral rubble, sea grass, under large pieces of rubble, $0.5-2 \mathrm{~m}$, leg. A. Anker et al., 27.04.2015, MZUSP 33922; 1 spec., same collection data, MZUSP 34055; 1 spec., Isla Bastimentos, Cayo Coral (Coral Cay), fine sand, rubble, sea grass, under large piece of rubble, $0.5-2 \mathrm{~m}$, leg. A. Anker et al., 28.04.2015, MZUSP 33656.

Remarks. Currently known from the Caribbean coast of Panama, Costa Rica, British Virgin Islands, the Florida Keys and Campeche Bank in the Gulf of Mexico, but likely more widespread in the Caribbean Sea (Anker, 2012); under coral rubble on sand-rubble bottoms near sea grass and mangroves, 0-9 m.

\section{Alpheus schmitti Chace, 1972}

Previous records. Abele, 1976: 273 [around Colón]; Birkeland et al., 1976: 136 [Galeta reef]; Cubit and Williams, 1983: 24 [Galeta Point]; Knowlton and Weigt, 1998: 2258 [Caribbean Panama]; Williams et al., 2001: 377 [Caribbean Panama]; Hurt et al., 2009: 516 [Caribbean Panama].

Remarks. The species has been recorded from the Florida Keys, the eastern Gulf of Mexico and several localities in the Caribbean Sea, including Dominican Republic, Colombia and Panama (Felder et al., 2009); lives in self-constructed galleries inside dead corals, usually in exposed areas and in very shallow water (0-2 m).

\section{Alpheus simus Guérin-Méneville, 1856}

Previous records. Abele, 1976: 273 [around Colón, as Thunor rathbunae (Schmitt, 1924)]; Birkeland et al., 1976: 136/137 [Galeta reef, as A. simus and T. rathbunae]; Cubit and Williams, 1983: 24 [Galeta Point, as T. rathbunae]; Knowlton et al., 1993: 1630 [Caribbean Panama]; Knowlton and Weigt, 1998: 2258 [Caribbean Panama]; Williams et al., 2001: 377
[Caribbean Panama]; Wehrtmann and Albornoz, 2002: 606 [Aguadargana Island]; Bezerra and Almeida, 2008: 59 [Isla Grande]; Hurt et al., 2009: 516 [Caribbean coast of Panama]

Material examined. Bocas del Toro. 1 spec., Isla Solarte, Hospital Point, 09¹9.996’N 082¹3.161'W, in coral rubble in shallow water, leg. S. De Grave, 04.08.2000, OUMNH.ZC.2008-14-030; 2 spec., same collection data, leg. C. Ashelby, 04.08.2000, OUMNH. ZC.2008-14-131.

Remarks. Widely distributed from southern Florida southwards to Bahia, Brazil, including the Caribbean Sea and Gulf of Mexico (Soledade and Almeida, 2013); endolithic in coral rocks and dead coral heads, sometimes also in live corals, $1-10 \mathrm{~m}$.

\section{Alpheus thomasi Hendrix and Gore, 1973}

Previous records. Knowlton and Weigt, 1998: 2258 [Caribbean Panama]; Williams et al., 2001: 377 [Caribbean Panama]; Anker et al., 2008c: 54 [Bocas del Toro; Isla Grande].

Material examined. Bocas del Toro. 1 spec., Isla Colón, Boca del Drago, 09²4.924’N 082¹9.824’W, in rubble among sea grass, leg. S. De Grave, 10.08.2008, OUMNH.ZC.2008-14-115; 2 spec., Isla Colón, between STRI station and Playa Bluff, sand and fossil coral terrace, in crevices and under rubble, $0.3-1 \mathrm{~m}$, leg. A. Anker et al., 26.04.2015, MZUSP 33640; 1 spec., Isla Colón, Boca del Drago, in rubble crevices, $0.2-1.5$ m, leg. A. Anker et al., 01.05.2015, MZUSP 34040.

Remarks. Widely distributed in the western Atlantic, from Florida southwards to Paraná, Brazil, including most of the Caribbean Sea and southern Gulf of Mexico (Soledade and Almeida, 2013); occurs in a variety of mixed bottom habitats (reefs, lagoons, rocky and rocky-sandy shores etc.), 0-2 m.

\section{Alpheus vanderbilti Boone, 1930}

Previous records. Duffy, 1992: 131 [San Blas, as Alpheus cylindricus Kingsley, 1878]; Knowlton and Mills, 1992: 2 [Caribbean Panama, as A. cylindricus]; 


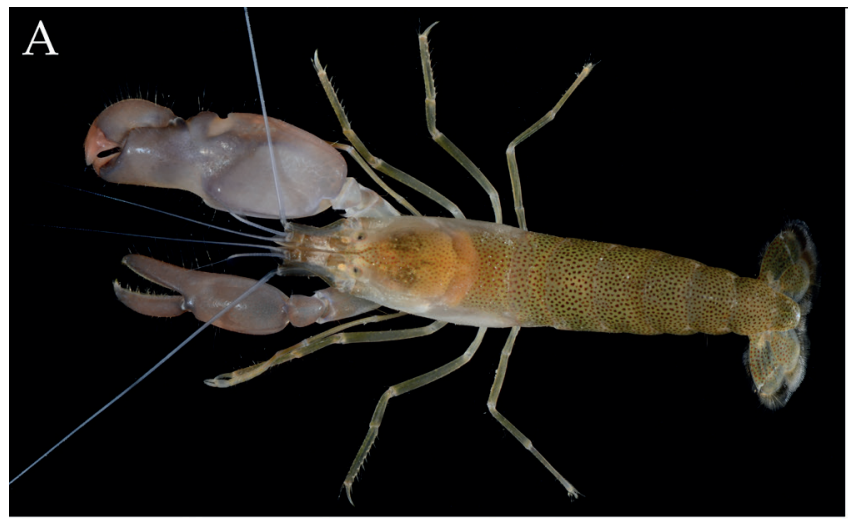

\section{B}
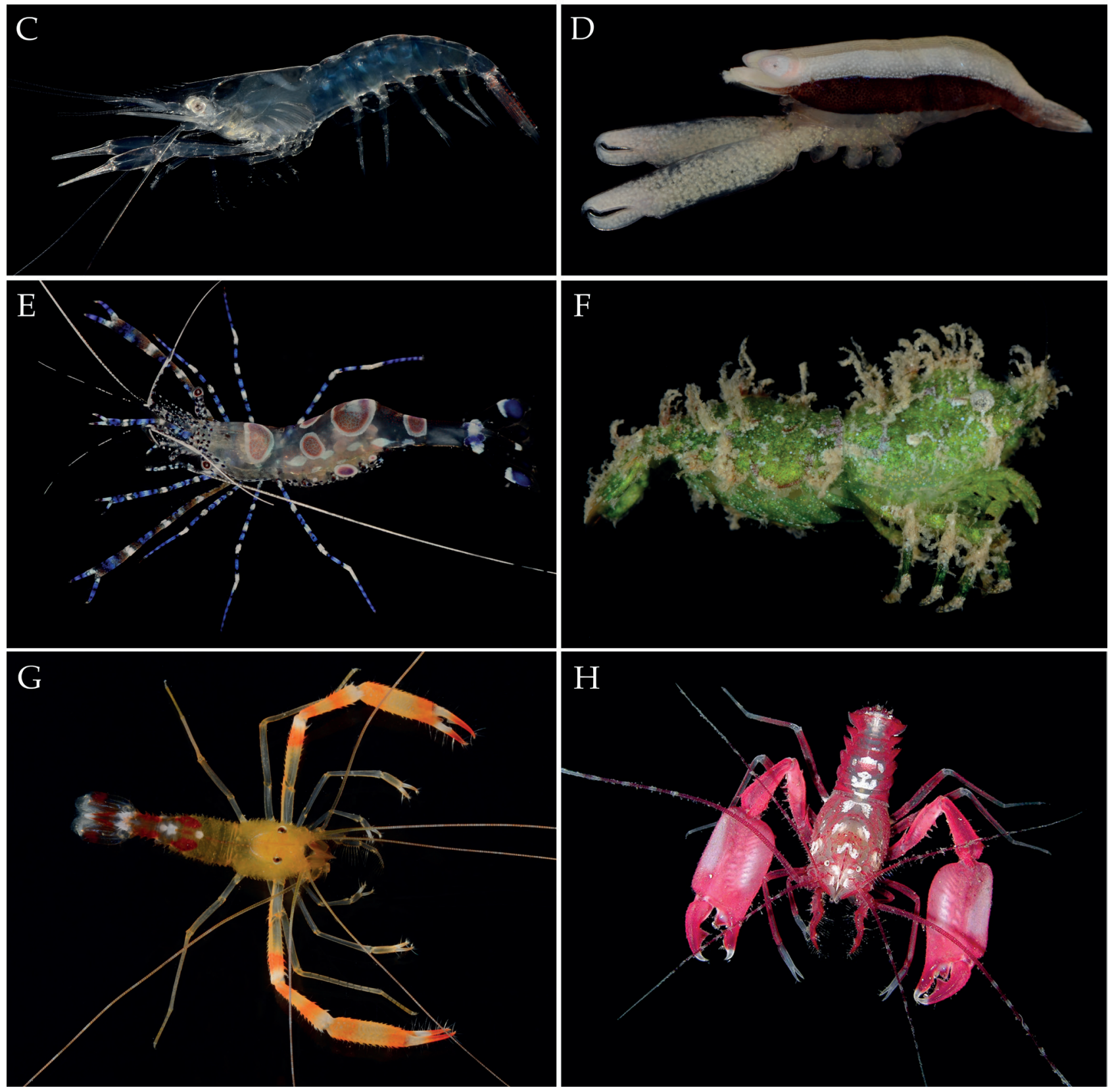

Figure 1. Six caridean and two stenopodidean shrimps found in shallow marine waters of the Caribbean coast of Panama. A, Alpheus punctatus Anker, 2012 (Alpheidae); B, Fenneralpheus orabovis Anker, 2011 (Alpheidae); C, Anchistioides antiguensis (Schmitt, 1924) (Anchistioididae); D, Gnathophylloides mineri Schmitt, 1933 (Palaemonidae); E, Periclimenes yucatanicus (Ives, 1891) (Palaemonidae); F, Trachycaris rugosa (Spence Bate, 1888) (Hippolytidae); G, Stenopus scutellatus Rankin, 1898 (Stenopodidae); H, Microprosthema semilaeve (von Martens, 1872) (Spongicolidae). 
Knowlton et al., 1993: 1630 [Caribbean Panama, as A. cylindricus]; Knowlton and Weigt, 1998: 2258 [Caribbean Panama, as A. cylindricus]; Williams et al., 2001: 377 [Caribbean Panama, as A. cylindricus]; Anker et al., 2008d: 60 [San Blas].

Remarks. Amphi-Atlantic species, in the western Atlantic recorded from Bermuda southwards to Bahia and Trindade Island, Brazil (Anker et al., 2016); on the Caribbean coast of Panama typically found inside large loggerhead sponges, Spheciospongia vesparia (Lamarck, 1814), in shallow water (less than $5 \mathrm{~m}$ ), but also recorded from deep-water rubble down to 45-67 $\mathrm{m}$. In older Atlantic literature known under the name A. cylindricus, which is now restricted to the tropical eastern Pacific (see Anker et al., 2008d).

\section{Alpheus verrilli (Schmitt, 1924)}

Previous records. Matthews and Anker, 2009: 277 [Bocas del Toro; as A. cf. armillatus I and A. cf. verrilli]; Anker, 2012: 22 [Bocas del Toro].

Remarks. Sparsely recorded from the Florida Keys southwards to São Paulo, Brazil, including some localities in the Caribbean Sea (Soledade and Almeida, 2013); typically found under larger rocks or coral rubble near reefs or rocky-sandy shores, 0-4 m.

\section{Alpheus viridari (Armstrong, 1949)}

Previous records. Abele, 1976: 273 [around Colón]; Heck and Wetstone, 1977: 200 [around Galeta]; Cubit and Williams, 1983: 24 [Galeta Point]; Williams et al., 2001: 377 [Caribbean Panama]; Anker et al., 2006: 2510 [Isla Grande]; Matthews and Anker, 2009: 277 [Bocas del Toro]; Anker, 2012: 85 [Isla Grande; Bocas del Toro].

Material examined. Bocas del Toro. 1 spec., Isla Colón, off STRI pier, $09^{\circ} 14.983^{\prime} \mathrm{N} 082^{\circ} 08.239^{\prime} \mathrm{W}$, sea grass bed, at night, leg. S. De Grave, 13.08.2008, OUMNH.ZC.2008-14-104; 1 spec., same location, under rocks on mud, $0.5 \mathrm{~m}$, leg. A. Anker, 05.08.2008, OUMNH.ZC.2008-14-094; 1 spec., same collection data, OUMNH.ZC.2008-14-110; 2 spec., Isla Colón, off STRI pier, sea grass bed, in burrows, leg. A. Anker et al., 12.08.2008, OUMNH.ZC.2010-01-021. Isla
Grande. 1 spec., southwestern side, under rocks on fine sand, leg. A. Anker et al., 21.04.2006, OUMNH. ZC.2010-01-019; 1 spec., same collection data, OUMNH.ZC.2011-03-055.

Remarks. Widely distributed in the tropical northwestern Atlantic, from southern Florida southwards to Venezuela, including the entire Caribbean Sea and southern parts of the Gulf of Mexico (Anker, 2012); typically encountered in sea grass beds or close to mangroves, in burrows or under large rocks, $0-3 \mathrm{~m}$.

\section{Alpheus websteri Kingsley, 1880}

Previous records. Birkeland et al., 1976: 136 [Galeta reef, as Alpheus ridleyi Pocock, 1890]; Cubit and Williams, 1983: 24 [Galeta Point, as A. ridleyi]; Knowlton and Weigt, 1998: 2258 [Caribbean Panama]; Williams et al., 2001: 377 [Caribbean Panama]; Anker et al., 2008c: 54 [Bocas del Toro; Isla Grande].

Material examined. Bocas del Toro. 2 spec., Isla Bastimentos, Playa Polo, in coral rubble, 1-2 m, leg. A. Anker et al., 29.04.2015, MZUSP 33575. Isla Grande. 1 spec., south-western point, in rubble crevices, less than 2 m, leg. A. Anker et al., 27.03.2015, MZUSP 33599.

Remarks. Rarely collected but relatively widespread in the western Atlantic, from the Florida Keys southwards to Atol das Rocas, off north-eastern Brazil, including much of the Caribbean Sea and southern Gulf of Mexico (Soledade and Almeida, 2013); typically encountered on coral or rocky reefs, $0-10 \mathrm{~m}$.

\section{Automate dolichognatha De Man, 1888 sensu lato}

Material examined. Bocas del Toro. 1 spec., Isla Colón Boca del Drago, 09²4.764’N 082¹9.868'W, under rocks, $0.5-1 \mathrm{~m}$, leg. A. Anker, 04.08.2008, OUMNH.ZC.2008-14-109; 1 spec., Isla Carenero, eastern side, $09^{\circ} 20.675^{\prime} \mathrm{N} 082^{\circ} 13.762^{\prime} \mathrm{W}$, under rocks and coral rubble, $0.5 \mathrm{~m}$, leg. A. Anker, 06.08.2008, OUMNH.ZC.2008-14-097.

Remarks. Automate dolichognatha is an almost pantropical taxon, absent only in the eastern Atlantic 
(where it appears to be "replaced" by the closely related Automate talismani Coutière, 1900) (Anker et al., 2016). However, the morphological variability and some differences in the colouration suggest that it might represent a species complex. The material from Bocas del Toro is the first record of $A$. dolichognatha for the Caribbean coast of Panama.

\section{Automate evermanni Rathbun, 1901 sensu lato}

Previous records. Hernáez et al., 2010: 694 [Bocas del Toro].

Material examined. Bocas del Toro. 1 spec., Isla Colón, off STRI dock, by yabby pump, leg. A. Anker et al., 09.08.2008, OUMNH.ZC.2016-01-033.

Remarks. Possibly transisthmian and amphi-Atlantic species complex (A. Anker, pers. obs.); in the western Atlantic occurring from Virginia and the northern Gulf of Mexico southwards to São Paulo, Brazil, including much of the Caribbean Sea and Gulf of Mexico (Almeida et al., 2012); facultative associate of ghost shrimps (Callianassidae), 0-250 m.

\section{Automate rectifrons Chace, 1972}

Previous records. Birkeland et al., 1976: 136 [Galeta reef]; Cubit and Williams, 1983: 24 [Galeta Point].

Material examined. Isla Grande. La Guaria, leg. A. Anker and A. Baeza, 04.08.2007, OUMNH.ZC.201601-034.

Remarks. Sparsely recorded from Florida southwards to Panama (Felder et al., 2009); most frequently encountered in coral rubble, $0-15 \mathrm{~m}$.

\section{Fenneralpheus chacei Felder and Manning, 1986}

Previous records. Anker, 2011 a: 28 [Bocas del Toro].

Material examined. Bocas del Toro. $1 \mathrm{spec}$. Isla Colón, Boca del Drago, sea grass bed with sand patches, 0.2-1.5 m, leg. A. Anker et al., 01.05.2015, MZUSP 33574 .
Remarks. This rarely collected species is known only from two localities, southern Florida (near Fort Pierce) and Caribbean Panama (Bocas del Toro) (Anker, 2011a), but is presumably more widespread in the Caribbean Sea; always encountered in burrows in mud or fine sand, however, the host animal remains unknown; probably confined to intertidal and shallow subtidal waters, with one specimen found in the stomach of a sand perch taken at $31 \mathrm{~m}$.

\section{Fenneralpheus orabovis Anker, 2011}

(Fig. 1B)

Previous records. Anker, 2011a: 32 [Bocas del Toro].

Material examined. Isla Grande. 1 spec., SW part, muddy bottom, 1-1.5 m, leg. A. Anker et al., 27.03.2015, OUMNH.ZC.2015-08-003; 1 spec., same collection data, MZUSP 33542.

Remarks. Presently known only from the type series from Isla Bastimentos in the Bocas del Toro Archipelago (Anker, 2011a) and two additional specimens from Isla Grande (present material); inhabits burrows of yet unknown hosts, in shallow water (less than $1.5 \mathrm{~m}$ ).

\section{Leptalpheus felderi Anker, Vera Caripe and Lira, 2006}

Previous records. Anker, 2011a: 8 [Bocas del Toro].

Remarks. Presently known only from the southern Caribbean Sea: Venezuela, Colombia and Panama (Anker, 2011a); associated with mud shrimps of the genus Upogebia Leach, 1814, in very shallow water (0-1 m).

\section{Leptalpheus cf. forceps Williams, 1965}

Previous records. Anker, 2011a: 6 [Bocas del Toro]. Material examined. Bocas del Toro. 1 spec., Isla Colón, west of Punta Caracol, 09²2.410’N $082^{\circ} 17.887^{\prime} \mathrm{W}$, suction pump, from burrow of Lepidophthalmus cf. sinuensis Lemaitre and Rodrigues, leg. A. Anker, 11.08.2008, OUMNH.ZC.2008-14-119. 
Remarks. The Panamanian specimens are provisionally assigned to $L$. forceps following Anker (2011a), as they show some minor morphological differences to the populations from North Carolina (type locality) and elsewhere. Recorded from North Carolina southwards to Panama and Ceará, Brazil (Pachelle et al., 2016); associated with several species of ghost and mud shrimps (Callianassidae, Upogebiidae) in very shallow water $(0-5 \mathrm{~m})$.

\section{Leptalpheus pereirai Anker and Vera Caripe, 2016}

Previous records. Anker, 2011 a: 24 [Bocas del Toro, as Leptalpheus sp. 1]; Anker and Vera Caripe, 2016: 186 [Isla Grande; between Colón and Portobelo; Bocas del Toro].

Remarks. Presently known only from Panama and Venezuela (Anker and Vera Caripe, 2016); probably associated with the large ghost shrimp Glypturus acanthochirus Stimpson, 1866, 0-2 m.

\section{Leptalpheus pierrenoeli Anker, 2008}

Previous records. Anker, 2008: 783 [Isla Grande].

Remarks. Presently known only from the holotype collected on the southern shore of Isla Grande, Panama, from a burrow of an unknown host (Anker, 2008).

\section{Metalpheus rostratipes (Pocock, 1890)}

Previous records. Birkeland et al., 1976: 137 [Galeta reef]; Cubit and Williams, 1983: 24 [Galeta Point].

Material examined. Isla Grande. 1 spec., western point, in coral rocks, $0.5-1 \mathrm{~m}$, leg. A. Anker et al., 06.10.2005, OUMNH.ZC.2011-03-048; 1 spec., north-eastern side, in coralline algae and coral rocks, leg. A. Anker et al., 16.09.2007, OUMNH.ZC.201001-051.

Remarks. A pantropical taxon, in the western Atlantic recorded from Puerto Rico southwards to Fernando do Noronha, off northeastern Brazil, including the eastern Gulf of Mexico (Anker et al., 2016); living in crevices of coralline algae and dead corals, 0-12 m.

\section{Salmoneus armatus Anker, 2010}

Previous records. Anker, 2010a: 181 [Isla Grande; Bocas del Toro].

Remarks. This species remains known only from two specimens, one from Isla Grande and the other from the Bocas del Toro (Anker, 2010a); inhabits small spaces under rocks in water less than $1 \mathrm{~m}$ deep.

\section{Salmoneus camaroncito Anker, 2010}

Previous records. Anker, 2010a: 184 [Isla Grande; San Blas Islands].

Remarks. Presently known only from Panama (Isla Grande, San Blas Islands) and Honduras (Bay Islands) (Anker, 2010a); under coral rubble in very shallow water (less than $1.5 \mathrm{~m}$ ).

\section{Salmoneus cavicolus Felder and Manning, 1986}

Material examined. Bocas del Toro. 1 spec., Isla Carenero, eastern side, near Buccaneer, shallow sea grass flat, $0.5-1 \mathrm{~m}$, suction pump, leg. A. Anker and I.N. Marin, 02.05.2007, OUMNH.ZC.2015-08-029.

Remarks. Only known from Indian River Lagoon (Florida, USA), Turks and Caicos Islands (Anker, 2010a) and now Panama; associated with burrows of unknown hosts on sandy mud flats, sometimes among or proximal to sea grass beds, $0.5-3 \mathrm{~m}$.

\section{Salmoneus degravei Anker 2010}

Previous records. Anker, 2010a: 188 [Isla Grande].

Remarks. Currently known only from the southern Caribbean Sea: Panama (both records from Isla Grande), Colombia, Venezuela and Tobago (Anker, 2011a); likely a commensal in burrows of ghost shrimps, Neocallichirus spp., 0-1 m.

\section{Salmoneus depressus Anker, 2011}

Previous records. Anker, 201 1b: 44 [Bocas del Toro; San Blas Islands]. 
Remarks. Although described only recently, $S$. depressus appears to be widely distributed in the western Atlantic, being known from Panama, Venezuela, St. Martin, Barbados and São Paulo, Brazil (Anker et al., 2013); typically found under rocks or coral rubble on sand flats, $0-7 \mathrm{~m}$.

\section{Salmoneus ortmanni (Rankin, 1898)}

Previous records. Birkeland et al., 1976: 137 [Galeta Point]; Cubit and Williams, 1983: 24 [Galeta Point]; Anker, 2010a: 199 [Isla Grande; Portobelo; Bocas del Toro].

Material examined. Bocas del Toro. 1 spec., Isla Colón, Puss Head Point, 09²1.802’N 082¹4.333’W, under coral rubble, 1-2 m, leg. A. Anker, 09.08.2008, OUMNH.ZC.2008-14-092.

Remarks. Widespread in the western Atlantic from Bermuda southwards to São Paulo, Brazil, including much of the Caribbean Sea and Gulf of Mexico (Anker et al., 2013); under rocks and rubble and in crevices of dead corals, $0-22 \mathrm{~m}$.

\section{Salmoneus wehrtmanni Anker, 2010}

Previous records. Anker et al., 2006: 2510 [Isla Grande, as S. ortmanni]; Anker, 2010a: 193 [Isla Grande; La Guaira; Bocas del Toro; San Blas Islands].

Remarks. Appears to be widespread in the Caribbean Sea, being known from Panama (several localities, see above), Honduras (Bay Islands), Mexico (Quintana Roo) and Tobago (Anker, 2010a); under rocks and rubble on fine sand, $0-2 \mathrm{~m}$.

\section{Synalpheus cf. africanus Crosnier and Forest, 1965}

Previous records: (?) Abele, 1976: 273 [around Colón, as Synalpheus tenuispina Coutière, 1909]; (?) Birkeland et al., 1976: 137 [Galeta reef, as S. tenuispina]; (?) Cubit and Williams, 1983: 24 [Galeta Point, as S. tenuispina]; Anker et al., 2012: 9 [Bocas del Toro].

Remarks. The true identity of the western Atlantic material assigned to this taxon in Anker et al. (2012) is unclear. Earlier records listed above likely refer to the same taxon and not S. tenuispina, a much larger species originally described from southern Brazil (see Anker and Pachelle, 2014 for a redescription).

\section{Synalpheus agelas Pequegnat and Heard, 1979}

Previous records. Duffy, 1992: 131 [San Blas Islands]; Ríos and Duffy, 2007; 8 [San Blas Islands, as Zuzalpheus agelas].

Remarks. Widespread western Atlantic species, distributed from Texas southwards to Trindade Island, Brazil, including much of the Caribbean Sea (Anker et al., 2016); exclusively associated with sponges of the genus Agelas Duchassaing and Michelotti, 1864, in male-female pairs, $1-91 \mathrm{~m}$.

\section{Synalpheus anasimus Chace, 1972}

Previous records. Birkeland et al., 1976: 137 [Galeta reef]; Duffy, 1992: 131 [San Blas Islands]; Cubit and Williams, 1983: 24 [Galeta Point]; Morrison et al., 2004: 574 [Porvenir, San Blas Islands]; Hultgren et al., 2014: Suppl. [Caribbean Panama].

Remarks. Widely distributed but rather uncommon species, known from Veracruz, Yucatan and Quintana Roo in Mexico, as well as Cuba, St. Martin and Panama (Anker et al., 2012); in coral rubble, 0-3 m.

\section{Synalpheus androsi Coutière, 1909}

Previous records. Hultgren and Duffy, 2011: 356 [Caribbean Panama].

Remarks. Hultgren and Duffy (2011) included “S. androsi (Panama)" as a terminal in their phylogram, but only listed material from Belize under sequenced material. Thus, the presence of $S$. androsi in Panama requires confirmation. This pair-living species is known from only a few localities in the Caribbean Sea, Bahamas and north-eastern Brazil; lives in various sponges, 14-55 m (Anker and Pachelle, 2014).

\section{Synalpheus ankeri Hultgren and Brandt, 2015}

Previous records. Hultgren and Duffy, 2011: 356 
[Bocas del Toro, as Synalpheus paraneptunus-4]; Hultgren and Brandt, 2015: 549 [Panama].

Remarks. This recently described pair-living species from the Synalpheus paraneptunus Coutière, 1909 complex is currently known only from Belize and Panama; associates with several sponge species, 0.5-10 m (Hultgren and Brandt, 2015).

\section{Synalpheus antillensis Coutière, 1909}

Previous records. Anker et al., 2012: 16 [Isla Grande; La Guiara]; Hultgren et al., 2014: Suppl. [Caribbean Panama].

Material examined. Bocas del Toro. 1 spec., Isla Solarte, Hospital Point, $09^{\circ} 20.016^{\prime} \mathrm{N} 082^{\circ} 13.133^{\prime} \mathrm{W}$, in coral rubble, $3 \mathrm{~m}$, leg. S. De Grave, 06.08.2005, OUMNH.ZC.2005-10-087.

Remarks. Widely distributed in the western Atlantic, from coral reefs off Texas southwards to São Paulo, Brazil, including the entire Caribbean Sea and some oceanic islands of Brazil (Anker et al., 2012; 2016); in crevices of dead corals, coralline algae etc., 1-42 m. The distributional record for Bocas del Toro, Panama, in Anker et al. (2012) refers to the above sample.

\section{Synalpheus apioceros Coutière, 1909}

Previous records. Abele, 1976: 273 [around Colón]; Heck, 1979: 200 [Caribbean Panama, as S. apiocerus, lap. cal.]; Abele and Kim, 1989: 15 [Gatun Locks]; Anker et al., 2012: 21 [Bocas del Toro]; Rebolledo et al., 2014: 227 [Bocas del Toro].

Remarks. Widely distributed in the western Atlantic, from Florida southwards to Santa Catarina, Brazil; found in a variety of rocky and coral reef habitats, $0-20 \mathrm{~m}$. The species is morphologically variable and may comprise a species complex (Anker et al., 2012).

\section{Synalpheus barahonensis Armstrong, 1949}

Previous records. Duffy, 1992: 131 [San Blas Islands].

Remarks. Rare species, known only from the original description based on material from the Dominican
Republic (Armstrong, 1941) and the above record from San Blas Islands (Panama), which requires confirmation. Associated with sponges; depth range unknown.

\section{Synalpheus bocas Anker and Tóth, 2008}

Previous records. Tóth and Bauer, 2008: 51 [Bocas del Toro; as S. paraneptunus A]; Anker and Tóth, 2008: 17 [Bocas del Toro]; Hultgren et al., 2014: Suppl. [Caribbean Panama].

Remarks. This species is currently known only from the western Caribbean Sea, with records from Panama, Curaçao and Jamaica (Macdonald et al., 2009); associated with sponges of the genus Xestospongia de Laubenfels, 1932, 0.5-15 m.

\section{Synalpheus bousfieldi Chace, 1972}

Previous records. Anker et al., 2012: 24 [Bocas del Toro].

Remarks. Widely distributed in the western Atlantic, from the northern Gulf of Mexico and the Bahamas southwards to Bahia, Brazil (Macdonald et al., 2009); inhabiting a variety of sponges at depths of 5-20 m.

\section{Synalpheus brevicarpus Herrick, 1891 sensu lato}

Previous records. Cubit and Williams, 1983: 24 [Galeta Point, as S. brevidactylus, lap. cal.]; Duffy, 1992: 131 [San Blas Islands, as Synalpheus sp. D (near brevicarpus)]; Morrison et al., 2004: 575 [San Blas Islands; not Isla Bartolomé, see below].

Material examined. Bocas del Toro. 7 spec., Isla Solarte, Hospital Point, $09^{\circ} 20.016^{\prime} \mathrm{N} 082^{\circ} 13.133^{\prime} \mathrm{W}$, in Xestospongia rosariensis Zea and Rützler, 1983, leg. S. De Grave, 06.08.2005, OUMNH.ZC.2005-10-077; 1 spec., Swan Cay, 09²7.200’N 082 17.900'W, in Ircinia strobilina (Lamarck, 1816), 3 m, leg. S. De Grave, 04.08.2005, OUMNH.ZC.2005-10-080; 2 spec., Isla San Cristobal, eastern side, Laguna Porras, $09^{\circ} 17.342^{\prime} \mathrm{N}$ $082^{\circ} 15.384^{\prime} \mathrm{W}$, in Mycale (Arenochalina) laxissima (Duchassaing and Michelotti, 1864), $7 \mathrm{~m}$, leg. S. De Grave, 03.08.2005, OUMNH.ZC.2005-10-078. 
Remarks. Widely distributed in the western Atlantic, however, comprised of several genetically, morphologically and chromatically distinct species (Hultgren et al., 2014), of which several are present in Panama. The record of S. brevicarpus from Isla Bartolomé in the Las Perlas Archipelago, on the Pacific side of Panama (Morrison et al., 2004), most likely refers to one of the three cryptic species in the Synalpheus digueti Coutière, 1909 complex (see Hultgren et al., 2014).

\section{Synalpheus brevidactylus Anker and Tóth, 2008}

Previous records. Anker and Tóth, 2008: 14 [Isla Grande; Bocas del Toro].

Remarks. Only known from the original description; pair living in crevice-boring sponges, $1-3 \mathrm{~m}$. The validity of this species needs to be confirmed by a molecular analysis.

\section{Synalpheus brevifrons Chace, 1972}

Previous records. Ríos and Duffy, 2007: 13 [?San Blas Islands, as Zuzalpheus brevifrons].

Remarks. The presence of S. brevifrons in Panama requires confirmation. Ríos and Duffy (2007) first stated that this species is possibly present in San Blas Islands, but after having provided some details about the single ovigerous female from San Blas, the authors concluded that it may represent "yet another undescribed species". Otherwise S. brevifrons is known only from the Dominican Republic and Belize (Anker et al., 2012), where it associates with the sponge Aiolochroia crassa (Hyatt, 1875) at depths of 1-15 m.

\section{Synalpheus brooksi Coutière, 1909}

Previous records. Duffy, 1992: 131 [San Blas Islands]; Duffy, 1993: 461 [San Blas Islands]; Morrison et al., 2004: 574 [San Blas Islands; as S. brooksi A]; Ríos and Duffy, 2007: 15 [San Blas, as Zuzalpheus brooksi]; Hultgren and Duffy, 2011: 356 [Bocas del Toro]; Hultgren and Duffy, 2011: 356 [Caribbean Panama; as S. cf. brooksi]; Anker et al., 2012: 26 [Bocas del Toro; Isla Grande]; Hultgren et al., 2014: Suppl. [Caribbean Panama].
Remarks. Widely distributed in the western Atlantic, from Florida southwards to Bahia, Brazil, including much of the Caribbean Sea and parts of the Gulf of Mexico (possibly a species complex) (Anker et al., 2012); lives in subsocial groups in a variety of sponges; 1-73 m, most abundant shallower than $10 \mathrm{~m}$.

\section{Synalpheus carpenteri Macdonald and Duffy, 2006}

Previous records. Morrison et al., 2004: 575 [San Blas Islands; as Synalpheus bousfieldi A]; Macdonald and Duffy, 2006: 3 [San Blas Islands]; Ríos and Duffy, 2007: 16 [San Blas Islands, as Zuzalpheus carpenteri (Macdonald and Duffy, 2006)]; Hultgren et al., 2014: Suppl. [Caribbean Panama].

Remarks. Known from Belize, Panama, Jamaica, St Martin and the Bahamas (Anker et al., 2012); in malefemale pairs or small subsocial groups in sponges of the genus Agelas, 10-20 m.

\section{Synalpheus chacei Duffy, 1998}

Previous records. Duffy, 1992: 131 [San Blas Islands, as S. bousfieldi Chace, 1972]; Duffy, 1998: 389 [San Blas Islands]; Ríos and Duffy, 2007: 43 [Caribbean Panama, as Zuzalpheus chacei]; Hernáez et al., 2010: 694 [Bocas del Toro]; Anker et al., 2012: 33 [Bocas del Toro].

Material examined. Bocas del Toro. many spec., Isla Colón, west of Punta Caracol, 09²2.410’N $082^{\circ} 17.887^{\prime} \mathrm{W}$, from Xestospongia rosariensis, leg. B. Martínez-Guerrero, 13.08.2008, OUMNH.ZC.200814-124.

Remarks. Presently known only from Belize, Panama and the British Virgin Islands (Anker et al., 2012); lives in eusocial groups of up to 80 individuals (queen, king(s), and numerous colony members) in a variety of sponges, 2-20 m.

\section{Synalpheus dardeaui (Ríos and Duffy, 2007)}

Previous records. Morrison et al., 2004: 574 [Limones, as "pandionis giant"]; Hultgren et al., 
2010: 225 [Panama]; McGrew and Hultgren, 2011: 196 [Bocas del Toro]; Anker et al., 2012: 34 [Bocas del Toro]; Hultgren, 2014: 1222 [Bocas del Toro]; Hultgren et al., 2014: Suppl. [Caribbean Panama].

Remarks. One of the largest sponge-dwelling species of Synalpheus Spence Bate, 1888; known with certainty from Belize, Panama, Curaçao, Florida and Bahia, Brazil (Anker et al., 2012); typically in male-female pairs in a variety of sponges, $1-65 \mathrm{~m}$.

\section{Synalpheus disparodigitus Armstrong, 1949}

Previous records. Duffy, 1992: 131 [San Blas Islands]; Hultgren et al., 2014: Suppl. [Caribbean Panama].

Remarks. Only known from a few records from the Dominican Republic, Grenadines, Venezuela and Panama (Anker et al., 2012); ecology poorly known, apparently free-living in crevices of coral rocks in shallow water.

\section{Synalpheus dominicensis Armstrong, 1949}

Previous records. Duffy, 1992: 131 [San Blas Islands]; Morrison et al., 2004: 575 [San Blas]; Anker et al., 2012: 37 [Isla Grande].

Remarks. Sparsely recorded in the western Atlantic from the Bahamas and southwestern Gulf of Mexico to the Dominican Republic and Panama (Anker et al., 2012); typically in female-male pairs on rock or coral crevices, at depths of $0-14 \mathrm{~m}$.

\section{Synalpheus duffyi Anker and Tóth, 2008}

Previous records. Tóth and Bauer, 2008: 51 [Isla Grande; as S. paraneptunus "small”]; Anker and Tóth, 2008: 7 [Isla Grande; La Guaira].

Remarks. Known with certainty only from Panama and Jamaica, possibly also occurs in the Florida Keys (Anker et al., 2012); lives in eusocial groups composed of a queen, one or several kings and up to 80 colony members, in a variety of sponges, $0-2 \mathrm{~m}$.

\section{Synalpheus elizabethae (Ríos and Duffy, 2007)}

Previous records. Duffy, 1996: 309 [San Blas Islands, as S. "rathbunae A"]; Morrison et al., 2004: 575 [San Blas, as S. "rathbunae A"]; Hultgren and Duffy, 2011: 356 [Bocas del Toro]; McGrew and Hultgren, 2011: 196 [Bocas del Toro]; Anker et al., 2012: 39 [Bocas del Toro; Isla Grande]; Hultgren, 2014: 1222 [Bocas del Toro]; Hultgren et al., 2014: Suppl. [Caribbean Panama].

Remarks. Uncommon in the western Atlantic, with scattered records from the Florida Keys and the southwestern Gulf of Mexico to Panama (Anker et al., 2012); lives in eusocial groups of up to several hundred colony members and one reproductive female (queen); associated with several sponge species, $0-18 \mathrm{~m}$.

\section{Synalpheus filidigitus Armstrong, 1949}

Previous records. Anker et al., 2012: 40 [Bocas del Toro].

Remarks. Known with certainty only from the Dominican Republic, Belize and Panama (Anker et al., 2012); lives in eusocial groups of up to a few hundreds of colony members and one reproductive female; associated with several sponge species, $0-15 \mathrm{~m}$.

\section{Synalpheus fritzmuelleri Coutière, 1909}

Previous records. Abele, 1976: 273 [around Colón]; Birkeland et al., 1976: 137 [Galeta reef]; Heck, 1977: 338 [around Galeta Island]; Heck, 1979: 199 [Caribbean Panama]; Cubit and Williams, 1983: 24 [Galeta Point]; Duffy, 1992: 131 [San Blas Islands]; Morrison et al., 2004: 575 [San Blas, not Isla Bartolomé, see below]; Anker et al., 2012: 41 [Isla Grande; Bocas del Toro].

Remarks. One of the most common and widely distributed species in the western Atlantic, ranging from North Carolina and the northern Gulf of Mexico to Santa Catarina, Brazil, including the entire Caribbean Sea, and some isolated islands in the Central Atlantic 
(Anker et al., 2012; 2016); lives in male-female pairs in a variety of microhabitats on coral reefs and rocky shore habitats, $0-51 \mathrm{~m}$. The record of S. fritzmuelleri from Isla Bartolomé in the Las Perlas Archipelago, on the Pacific side of Panama (Morrison et al., 2004), refers to a different eastern Pacific species, the identity of which remains to be determined.

\section{Synalpheus goodei Coutière, 1909}

Previous records. Coutière, 1909: 61 [near Colón]; Heck, 1979: 200 [Caribbean Panama]; Duffy, 1992: 131 [San Blas Islands]; Hultgren et al., 2010: 225, 230 [Isla San Cristóbal, Bocas del Toro]; Anker et al., 2012: 46 [Bocas del Toro; Isla Grande].

Material examined. Bocas del Toro. 1 spec., Isla Cristóbal, NW side, "Seagal”, 9.289 -82²96, leg. M. Leray et al., 27.05.2016, FLMNH UF 44521.

Remarks. Widely distributed in the western Atlantic, from Florida southwards to Tobago, and possibly further south to Brazil (Anker et al., 2012); typically found in male-female pairs in a variety of sponges, $1-20 \mathrm{~m}$.

\section{Synalpheus hemphilli Coutière, 1908}

Previous records. Duffy, 1992: 131 [San Blas Islands]; Anker et al., 2012: 49 [Bocas del Toro].

Remarks. Widely distributed in the western Atlantic, from North Carolina southwards to Bahia, Brazil, including Caribbean Sea and Gulf of Mexico (Anker et al., 2012; 2016); in male-female pairs, most often in tube sponges, $1-51 \mathrm{~m}$.

\section{Synalpheus herricki Coutière, 1909}

Previous records. Birkeland et al., 1976: 137 [Galeta reef]; Cubit and Williams, 1983: 24 [Galeta Point].

Material examined. Bocas del Toro. 10 spec., Isla San Cristóbal, eastern side, Laguna Porras, $09^{\circ} 16.514^{\prime} \mathrm{N}$ $082^{\circ} 14.833^{\prime} \mathrm{W}$, from Agelas cf. dispar Duchassaing and Michelotti, 1864, 7 m, leg. S. De Grave, 02.08.2005, OUMNH.ZC.2005-10-083; 1 spec., Isla Bastimentos,
Cayo Coral, $09^{\circ} 15.028^{\prime} \mathrm{N} 082^{\circ} 07.897^{\prime} \mathrm{W}$, in coral rubble, 4 m, leg. S. De Grave, 07.08.2005, OUMNH. ZC.2005-10-082.

Remarks. Widely distributed but relatively uncommon western Atlantic species, ranging from southern Florida to the Caribbean Sea and Gulf of Mexico, and further south to Ceará, Brazil (Anker et al., 2012); lives in female-male pairs in a variety of sponges, $5-73 \mathrm{~m}$.

\section{Synalpheus hoetjesi Hultgren, Macdonald, and Duffy 2010}

Previous records. Anker et al., 2012: 57 [Bocas del Toro].

Material examined. Bocas del Toro. 1 spec., Isla Colón, Bocas del Toro town, west of airport runway, $9.342^{\circ}-82^{\circ} 260$, leg. M. Leray et al., 19.05.2016, FLMNH UF 44363; 1 spec., Isla Cristóbal, NW side, off Punta Juan, $9.301^{\circ}-82^{\circ} 294$, leg. G. Paulay, 20.05.2016, FLMNH UF 44415.

Remarks. Relatively rarely encountered species, presently known only from Curaçao, Panama and Barbados (Anker et al., 2012); typically found in malefemale pairs in several host sponge species, $1-6 \mathrm{~m}$.

\section{Synalpheus idios (Ríos and Duffy, 2007)}

Previous records. Morrison et al., 2004: 575 [San Blas Islands; Synalpheus brooksi D]; Ríos and Duffy, 2007: 36 [San Blas, as Zuzalpheus idios]; Hernáez et al., 2010: 694 [Bocas del Toro]; Anker et al., 2012: 57 [Bocas del Toro].

Remarks. Relatively uncommon species, so far reported only from Belize, Panama, Curaçao, St. Martin and Barbados (Anker et al., 2012); lives in small subsocial groups in a variety of sponges, $1-15 \mathrm{~m}$.

\section{Synalpheus kensleyi (Ríos and Duffy, 2007)}

Previous records. Ríos and Duffy, 2007: 43 [Bocas del Toro, as Zuzalpheus kensleyi]; Hultgren and Duffy, 2011: 356 [Bocas del Toro]; Anker et al., 2012: 59 [Bocas del Toro]. 
Remarks. Morphologically distinctive, but rather uncommon species, presently known only from Belize, Panama and the Dominican Republic (Anker et al., 2012); lives in male-female pairs in sponges in shallow water, $1-2 \mathrm{~m}$.

\section{Synalpheus longicarpus (Herrick, 1891)}

Previous records. Duffy, 1992: 131 [San Blas Islands]; Morrison et al., 2004: 574 [San Blas]; Ríos and Duffy, 2007: 36 [San Blas Islands, as Zuzalpheus longicarpus]; Hultgren et al., 2010: 225 [Caribbean Panama].

Remarks. Widely distributed in the western Atlantic, from North Carolina southwards to Ceará, Brazil (Anker et al., 2012); associated with sponges, e.g. common in the loggerhead sponge Spheciospongia vesparium (Lamarck, 1815), 0-60 m.

\section{Synalpheus mcclendoni Coutiere, 1910}

Previous records. Cubit and Williams, 1983: 24 [Galeta Point]; Duffy, 1992: 131 [San Blas]; Morrison et al., 2004: 574 [San Blas Islands].

Remarks. Uncommon species; known from the Florida Keys and a few scattered localities in the Caribbean Sea (e.g. Venezuela, Panama) and the eastern Gulf of Mexico (Anker et al., 2012); associated with sponges, $0-23 \mathrm{~m}$.

\section{Synalpheus minus (Say, 1818)}

Previous records. (?) Abele, 1976: 273 [around Colón]; (?) Birkeland et al., 1976: 137 [Galeta reef]; (?) Duffy, 1992: 131 [San Blas Islands]; (?) Morrison et al., 2004: 575 [San Blas Islands]; Hultgren et al., 2014: Suppl. [Caribbean Panama].

Remarks. Some of the Panamanian records of $S$. minus may refer to $S$. antillensis, S. brevicarpus or another taxon from the S. brevicarpus - minus species complex (see Hultgren et al., 2014). The exact distribution range of $S$. minus is poorly known, but the species is known with certainty from the south-eastern USA, several localities in the Caribbean Sea and Brazil (under Synalpheus minus bahiensis Coutière, 1909) (Anker et al., 2012; 2016).

\section{Synalpheus pandionis Coutière, 1909}

Previous records. Birkeland et al., 1976: 137 [Galeta reef]; Heck, 1977: 338 [around Galeta Island]; Heck, 1979: 198 [Caribbean Panama]; Cubit and Williams, 1983: 24 [Galeta Point]; Duffy, 1992: 131 [San Blas Islands]; Ríos and Duffy, 2007: 55 [San Blas, as Zuzalpheus pandionis]; Anker et al., 2012: 59 [Bocas del Toro].

Material examined. Bocas del Toro. 1 spec., Isla Colón, Boca del Drago, sea grass bed, leg. A. Anker, 02.08.2008, OUMNH.ZC.2008-14-099; 1 spec., Isla Solarte, Hospital Point, in sponge, leg. J.F. Lazarus, 04.08.2008, OUMNH.ZC.2008-14-136; 1 spec. Isla Colón, Boca del Drago, sea grass bed, $1 \mathrm{~m}$, leg. S. De Grave, 02.08.2008, OUMNH.ZC.2008-14-026.

Remarks. Widely distributed in the western Atlantic, ranging from Florida southwards to northern Brazil, including numerous localities in the Caribbean Sea and Gulf of Mexico (Anker et al., 2012); earlier records may refer to related taxa; lives in male-female pairs in several species of sponges, $0-80 \mathrm{~m}$.

\section{Synalpheus paraneptunus Coutière, 1909}

Previous records. Duffy, 1992: 131 [San Blas Islands]; Morrison et al., 2004: 574 [Portobelo]; Duffy, 2003: 229 [Caribbean Panama]; Ríos and Duffy, 2007: 57 [San Blas, as Zuzalpheus paraneptunus].

Remarks. Synalpheus paraneptunus is with certainty only known from the holotype from the Gulf of Morrosquillo, Colombia (Anker and Tóth, 2008; under material examined therein, "Panama" should be substituted by Colombia). All the above records from Panama, as well as those listed in Table I in Anker et al. (2012), need confirmation as they most likely refer to other species in the $S$. paraneptunus complex.

\section{Synalpheus pectiniger Coutière, 1907}

Previous records. Duffy, 1992: 131 [San Blas]; Duffy, 1993: 461 [San Blas Islands]; Morrison et al., 2004: 575 [San Blas]; Ríos and Duffy, 2007: 57 [San Blas Islands, as Zuzalpheus pectiniger]; Anker et al., 2012: 64 [Western Atlantic: Panama]. 
Remarks. Morphologically distinctive species, sparsely recorded from Florida southwards to Panama (Anker et al., 2012); associated with the loggerhead sponge $S$. vesparium, where it lives in male-female pairs, $0-52 \mathrm{~m}$.

\section{Synalpheus rathbunae Coutière, 1909}

Previous records. Duffy, 1992: 131 [San Blas Islands]; Duffy, 1996: 309 [San Blas Islands; as S. rathbunae B]; Morrison et al., 2004: 575 [San Blas Islands]; Tóth and Bauer, 2007: 1877 [Bocas del Toro]; Tóth and Duffy, 2005: 49 [Bocas del Toro]; Anker et al., 2012: 65 [Panama].

Remarks. A rather uncommon Caribbean species, known with certainty only from the Lesser Antilles (St. Thomas, St. Martin, Guadeloupe) and Panama (Anker et al., 2012), although likely more widespread in the region; lives in small eusocial groups in cryptic sponges, $10-55 \mathrm{~m}$.

\section{Synalpheus regalis Duffy, 1996}

Previous records. Anker et al., 2012: 65 [Bocas del Toro].

Remarks. Presently known from Belize, Jamaica and Panama (Anker et al., 2012); eusocial sponge-dwelling species, living in groups of up to several hundreds of individuals, including usually one reproductive female (queen), unknown number of reproductive males (possibly only one), and numerous non-reproductive colony members; typically below $6 \mathrm{~m}$ depth.

\section{Synalpheus ruetzleri Macdonald and Duffy, 2006}

Previous records. Macdonald and Duffy, 2006: 8 [San Blas Islands]; Ríos and Duffy, 2007: 62 [San Blas, as Zuzalpheus ruetzleri]; Hultgren and Duffy, 2011: 356 [Bocas del Toro].

Remarks. Uncommon species presently known only from Belize and Panama (Anker et al., 2012); usually as male-female pairs in various sponges, mainly Hymeniacidon cf. caerulea Pulitzer-Finali, 1986, in very shallow water.

\section{Synalpheus sanctithomae Coutière, 1909}

Previous records. Ríos and Duffy, 2007: 63 [Panama, as Zuzalpheus sanctithomae].

Remarks. Morphologically distinctive western Atlantic species, sparsely recorded from the Florida Keys southwards to seamounts off Rio de Janeiro and Trindade Island, Brazil (Anker et al., 2016); apparently pair-living, obligate symbiont of several sponge species; depth range $1-20 \mathrm{~m}$.

\section{Synalpheus scaphoceris Coutière, 1910}

Previous records. Duffy, 1992: 131 [San Blas Islands]; Hernáez et al., 2010: 694 [Bocas del Toro]; Anker et al., 2012: 66 [Bocas del Toro; Isla Grande].

Remarks. Widely distributed in the western Atlantic: common in the Florida Keys, Caribbean Sea and parts of the Gulf of Mexico, extending to São Paulo, Brazil (Anker et al., 2012); typically in male-female pairs in coral rock crevices, $0-30 \mathrm{~m}$.

\section{Synalpheus townsendi Coutière, 1909}

Previous records. Abele, 1976: 273 [around Colón]; Birkeland et al., 1976: 137 [Galeta reef]; Heck, 1979: 200 [Caribbean Panama]; Cubit and Williams, 1983: 24 [Galeta Point]; Duffy, 1992: 131 [San Blas Islands]; Anker et al., 2012: 70 [Bocas del Toro; Isla Grande].

Remarks. One of the most common and widespread species of Synalpheus in the western Atlantic, ranging from North Carolina southwards to Rio de Janeiro and Trindade Island, Brazil, including much of the Caribbean and Gulf of Mexico (Anker et al., 2012; 2016); typically found in female-male pairs in a variety of microhabitats, including coral rocks crevices, calcareous algae and sponges, $0-102 \mathrm{~m}$.

\section{Synalpheus ul (Ríos and Duffy, 2007)}

Previous records. Ríos and Duffy, 2007: 63 [San Blas Islands: Porvenir and Aguadargana Islands, as Zuzalpheus ul]; Hultgren et al., 2010: 225, 250 [Bocas del Toro]; Anker et al., 2012: 72 [Bocas del Toro; Isla Grande]. 
Remarks. Relatively common western Atlantic species recorded from Belize southwards to Bahia, Brazil, including Panama and several other localities in the Caribbean Sea (Almeida et al., 2012); typically found in male-female pairs in a variety of sponge hosts, 1-3 m.

\section{Synalpheus yano (Ríos and Duffy, 2007)}

Previous records. Ríos and Duffy, 2007: 74 [Bocas del Toro, as Zuzalpheus yano]; Hernáez et al., 2010: 692 [Bocas del Toro]; McGrew and Hultgren, 2011: 196 [Bocas del Toro]; Hultgren, 2014: 1222 [Bocas del Toro].

Remarks. Relatively common western Atlantic species recorded from western Florida and the southern Gulf of Mexico (Alacranes Reef) southwards to Ceará, Brazil, including Caribbean Sea (Belize, Jamaica, Panama) (Anker et al., 2012; 2016); pair-living spongeassociated species, $1-3 \mathrm{~m}$.

\section{Synalpheus williamsi Ríos and Duffy, 1999}

Previous records. Ríos and Duffy, 1999: 542 [San Blas Islands]; Ríos and Duffy, 2007: 68 [San Blas, as Zuzalpheus williamsi].

Remarks. Rare species, so far recorded only from Belize, Jamaica, Curaçao and Panama (Anker et al., 2012); obligate symbiont of the sponge $H$. caerulea and possibly other sponges, in shallow to moderately deep water (less than $20 \mathrm{~m}$ ).

\section{Triacanthoneus toro Anker, 2010}

Previous records. Anker, 2010b: 49 [Bocas del Toro]

Material examined. Bocas del Toro. $1 \mathrm{spec}$. Isla Bastimentos, Cayo Coral (Coral Cay), $0.5 \mathrm{~m}$, in burrow in fine sand, suction pump, leg. A. Anker et al., 28.04.2005, MZUSP 33675; 1 spec., NW side of Isla Popa, 0.5-2 m, leg. A. Anker et al., 30.04.2015, MZUSP 33674.

Remarks. Presently known only from the Bocas del Toro Archipelago in Panama (Anker, 2010b); under coral rubble on sandy substrate, sometimes in burrows, $1-7 \mathrm{~m}$.

\section{Family Anchistioididae Paulson, 1875}

\author{
Anchistioides antiguensis (Schmitt, 1924) \\ (Fig. 1C)
}

Material examined. Bocas del Toro. 4 spec., Isla San Cristóbal, eastern side, Laguna Porras, $09^{\circ} 17.342^{\prime} \mathrm{N}$ $082^{\circ} 15.384^{\prime} \mathrm{W}$, in osculum of Mycale (Arenochalina) laxissima, $7 \mathrm{~m}$, leg. S. De Grave, 03.08.2005, OUMNH. ZC.2005-10-018; 1 spec., Isla Solarte, Hospital Point, $09^{\circ} 20.016^{\prime} \mathrm{N} 082^{\circ} 13.113^{\prime} \mathrm{W}$, in osculum of Niphates erecta (Duchassaing and Michelotti, 1864), $15 \mathrm{~m}$, leg. S. De Grave, 06.08.2005, OUMNH.ZC.2005-10-020; 1 spec., same locality, in osculum of $M$. (A.) laxissima, 10 $\mathrm{m}$, leg. S. De Grave, 09.08.2005, OUMNH.ZC.200510-019; 1 spec., Cayo Coral (Coral Cay), 09 15.028’ N $082^{\circ} 07.897^{\prime} \mathrm{W}$, inside unidentified sponge, $10 \mathrm{~m}$, leg. S. De Grave, 07.08.2005, OUMNH.ZC.2005-10-021; 4 spec., Almirante, in Lissodendoryx (Lissodendoryx) colombiensis Zea and van Soest, 1986, leg. E. Tóth, 04.01.2007, OUMNH.ZC.2007-14-01.

Remarks. Widespread in the western Atlantic, from Bermuda southwards to Espírito Santo, Brazil, including the Gulf of Mexico and Caribbean Sea (Felder et al., 2009), with the present material representing new record for Panama. Although A. antiguensis has been recorded in older literature from a variety of habitats from the intertidal down to $118 \mathrm{~m}$ (summarised in Williams, 1984); all recent records, including the present ones, are based on specimens found in the oscula of larger sponges, suggesting that the species might be at least a facultative sponge associate.

\section{Family Hippolytidae Spence Bate, 1888}

\section{Hippolyte nicholsoni Chace, 1972}

Previous records. Fransen and Almeida, 2009: 845 [Bocas del Toro].

Material examined. Bocas del Toro. 1 spec., Isla Bastimentos, Cayo Coral (Coral Cay), 09 $14.502^{\prime} \mathrm{N}$ $082^{\circ} 08.288^{\prime} \mathrm{W}$, on gorgonian, $1 \mathrm{~m}$, leg. S. De Grave, 13.08.2008, OUMNH.ZC.2008-14-046. 
Remarks. Common Caribbean species, ranging from the British Virgin Islands to Panama (d'Udekem d'Acoz, 2007); usually associated with the sea plume, Antillogorgia americana (Gmelin, 1791), 1-12 m.

\section{Hippolyte obliquimanus Dana, 1852}

Previous records. Birkeland et al., 1976: 137 [Galeta reef, as Hippolyte curacaoensis Schmitt, 1924]; Cubit and Williams, 1983: 25 [Galeta Point, as H.curacaoensis]; Terossi and Mantelatto, 2012: 688 [Bocas del Toro].

Material examined. Bocas del Toro. 5 spec., Isla Colón, Boca del Drago, NE of Lime Point, $09^{\circ} 24.954^{\prime} \mathrm{N}$ $082^{\circ} 19.757^{\prime} \mathrm{W}$, from sea grass bed, $1 \mathrm{~m}$, leg. S. De Grave, 05.08.2005, OUMNH.ZC.2005-10-069; many spec., same collection data, OUMNH.ZC.2005-10071; same collection data, OUMNH.ZC.2005-10072; many spec., same collection data, OUMNH. ZC.2005-10-073; 5 spec., Isla Carenero, $09^{\circ} 20.775^{\prime} \mathrm{N}$ $082^{\circ} 13.667^{\prime} \mathrm{W}$, mixed algal wash, $6 \mathrm{~m}$, leg. S. De Grave, 04.08.2005, OUMNH.ZC.2005-10-070; 2 spec., Isla Carenero, $09^{\circ} 20.675^{\prime} \mathrm{N} 082^{\circ} 13.762^{\prime} \mathrm{W}$, on Sargassum sp., 0.5 m, leg. S. De Grave, 06.08.2008, OUMNH. ZC.2008-14-043; 5 spec., Isla Colón, Boca del Drago, $09^{\circ} 24.764^{\prime} \mathrm{N} 082^{\circ} 19.868^{\prime} \mathrm{W}$, muddy sea grass bed, leg. S. De Grave, 05.08.2008, OUMNH.ZC.2008-14044; 5 spec., Isla Colón, Boca del Drago, 09²4.764’ N $082^{\circ} 19.868^{\prime} \mathrm{W}$, sea grass bed, leg. A. Anker, 05.08.2008, OUMNH.ZC.2008-14-045.

Remarks. Common and widely distributed western Atlantic species, ranging from North Carolina southwards to Santa Catarina, Brazil, including the Gulf of Mexico and Caribbean Sea (Felder et al., 2009); on a variety of substrates, but most frequently living on algae and sea grass, $0-10 \mathrm{~m}$.

\section{Hippolyte zostericola (Smith, 1873)}

Previous records. Heck, 1977: 338 [around Galeta Island]; Heck, 1979: 199 [Caribbean Panama].

Material examined. Bocas del Toro. Many spec., Isla Colón, off STRI pier, 09¹4.983'N 08208.239’W, in sea grass bed, $1 \mathrm{~m}$, leg. S. LeCroy, 02.08.2005, OUMNH.ZC.2005-10-065; many spec., same location, leg. S. De Grave, 01.08.2005, OUMNH.ZC.200510-067; many spec., same location, leg. S. De Grave, 07.08.2005, OUMNH.ZC.2005-10-062; 5 spec., Isla Colón, Boca del Drago, NE of Lime Point, $09^{\circ} 24.954^{\prime} \mathrm{N}$ $082^{\circ} 19.757^{\prime} \mathrm{W}$, in red algae, $1 \mathrm{~m}$, leg. S. De Grave, 09.08.20005, OUMNH.ZC.2005-10-068; 3 spec., Isla Colón, Big Bight entrance, in sea grass bed (Thalassia sp.) adjacent to red mangroves, $1 \mathrm{~m}$, leg. S. LeCroy, 06.08.2005, OUMNH.ZC.2005-10-064; 3 spec., same collection data, OUMNH.ZC.2005-10-063; 1 spec., Isla San Cristobal, Boca Torito, in red algae on mangrove prop roots, $0.2 \mathrm{~m}$, leg. S. LeCroy, 09.08.2005, OUMNH.2005-10-066; 1 spec., same location, in Halimeda clumps in Thalassia bed next to red mangrove stand, mud bottom, 0.5 m, leg. S. LeCroy, 09.08.2005, OUMNH.ZC.2005-10-095.

Remarks. Widespread in the western Atlantic, ranging from Bermuda and Massachusetts southwards to Ceara, Brazil, including the Caribbean Sea and Gulf of Mexico (Felder et al., 2009); Wicksten's (1989) record from the Pacific coast of Colombia is highly doubtful; typically associated with sea grass and algae, $0-5 \mathrm{~m}$.

\section{Latreutes fucorum (Fabricius, 1798)}

Previous records. Heck, 1977: 338 [around Galeta Island]; Heck, 1979: 200 [Caribbean Panama]; Heck and Weinstein, 1989: 631 [Caribbean entrance to Panama Canal].

Material examined. Bocas del Toro. 1 spec., Isla Bastimentos, Cayo Coral, $09^{\circ} 13.433^{\prime} \mathrm{N} 082^{\circ} 06.180^{\prime} \mathrm{W}$, in algae Dictyota sp., 1-2 m, leg. C. Ashelby, 11.08.2008, OUMNH.ZC.2008-14-041; 1 spec., Isla Bastimentos, in sea grass bed, less than $1 \mathrm{~m}$, leg. A. Anker, 03.05.2007, OUMNH.ZC.2009-18-07; 2 spec., Isla Colón, Boca del Drago, NE of Lime Point, 09²4.954’N 082¹9.757’W, in sea grass bed, $1 \mathrm{~m}$, leg. S. De Grave, 10.08.2005, OUMNH.ZC.2005-10-023; 1 spec., Isla Colón, Boca del Drago, $09^{\circ} 24.764^{\prime} \mathrm{N} 082^{\circ} 19.868^{\prime} \mathrm{W}$, in sea grass, 0.5-1m, leg. L. Harris, 04.08.2008, OUMNH. ZC.2008-14-042; 1 spec., Isla Colón, Boca del Drago,, in sea grass bed, $1 \mathrm{~m}$, leg. S. De Grave, 02.08.2008, OUMNH.ZC.2008-14-040. 
Remarks. Amphi-Atlantic taxon, in the western Atlantic ranging from southern Newfoundland to Bahia, Brazil (Felder et al., 2009); in sea grass beds or on floating algae, $0-2 \mathrm{~m}$.

\section{Latreutes parvulus (Stimpson, 1871)}

Material examined. Bocas del Toro. 1 spec., Swan Cay, 09²7.200'N 082 $17.900^{\prime} \mathrm{W}$, on algae Macrorhyncha robusta (?) , $3 \mathrm{~m}$, leg. S. De Grave, 04.08.2005, OUMNH.ZC.2005-10-028; 2 spec., same collection data, OUMNH.ZC.2005-10-029; 2 spec., Isla Colón, Boca del Drago, NE of Lime Point, $09^{\circ} 24.954^{\prime} \mathrm{N} 082^{\circ} 19.757^{\prime} \mathrm{W}$, in sea grass, $1 \mathrm{~m}$, leg. $\mathrm{S}$. De Grave, 05.08.2005, OUMNH.ZC.2005-10-031; 1 spec., same collection data, OUMNH.2005-10-026; 2 spec., Isla Carenero, off eastern shore, $09^{\circ} 20.775^{\prime} \mathrm{N}$ $082^{\circ} 13.667^{\prime} \mathrm{W}$, from mixed algal washings (Sargassum etc.), $6 \mathrm{~m}$, leg. S. De Grave, 04.08.2005, OUMNH. ZC.2005-10-030; 2 spec., same collection data, OUMNH.ZC.2005-10-024; 1 spec., same location, on soft coral Antillogorgia bipinnata (Verrill, 1864), 6 $\mathrm{m}$, leg. S. De Grave, 04.08.2005, OUMNH.ZC.200510-025; 1 spec., Swan Cay, 09²7.200’N 082¹7.900’W, on algae Spyridia hypnoides, $3 \mathrm{~m}$, leg. S. De Grave, 04.08.2005, OUMNH.ZC.2005-10-027.

Remarks. Amphi-Atlantic taxon, in the western Atlantic ranging from New Jersey southwards to Argentina (Felder et al., 2009), with the present material being a new record for Panama; most frequently found in sea grass beds, but also occurs in a variety of other microhabitats, $0-44 \mathrm{~m}$

\section{Tozeuma carolinense Kingsley, 1878}

Previous records. Heck, 1977: 338 [around Galeta Island]; Heck, 1979: 198 [Caribbean Panama]; Heck and Weinstein, 1989: 631 [Caribbean entrance to Panama Canal].

Material examined. Bocas del Toro. 6 spec., Isla Colón, Boca del Drago, 09²4.764'N 082²19.868'W, intertidal and shallow subtidal sea grass flat, at night, leg. A. Anker, 05.08.2008, OUMNH.ZC.2008-14051; 4 spec., Isla Colón, off STRI pier, $09^{\circ} 14.983^{\prime} \mathrm{N}$ $082^{\circ} 08.239^{\prime} \mathrm{W}$, in sea grass, $1 \mathrm{~m}$, leg. S. De Grave,
01.08.2005, OUMNH.ZC.2005-10-060; many spec., Isla Colón, Boca del Drago, NE of Lime Point, $09^{\circ} 24.954^{\prime} \mathrm{N} 082^{\circ} 19.757^{\prime} \mathrm{W}$, in sea grass, $1 \mathrm{~m}$, leg. $\mathrm{S}$. De Grave, 05.08.2005, OUMNH.ZC.2005-10-061; 7 spec., same collection data, OUMNH.ZC.2005-10059; 2 spec., same collection data, OUMNH.ZC.200510-058; many spec., same location, leg. S. De Grave, 10.08.2005, OUMNH.ZC.2005-10-057.

Remarks. Widespread in the western Atlantic, ranging from Massachusetts southwards to São Paulo, Brazil, including much of the Caribbean Sea and Gulf of Mexico (Felder et al., 2009); most common in sea grass beds and algal mats, $0-72 \mathrm{~m}$.

\section{Trachycaris rugosa (Spence Bate, 1888)}

(Fig. 1F)

Previous records. Heck, 1977: 338 [around Galeta Island, as Trachycaris restrictus (A. Milne-Edwards, 1878)]; Heck, 1979: 199 [Caribbean Panama]; Heck and Weinstein, 1989: 631 [Caribbean entrance to Panama Canal, as T. restrictus].

Material examined. Colón. 1 spec., near Portobelo, shallow subtidal flat with coral rubble, $0.5-1.5 \mathrm{~m}$, leg. A. Anker et al., 26.03.2015, MZUSP 33787.

Remarks. Criales (1992) showed that T. restricta does not occur in the western Atlantic; therefore all records of T. restricta from Panama must be referred to T. rugosa. The species is known from South Carolina southward to Colombia, with scattered records throughout the Caribbean Sea and the southwestern Gulf of Mexico (Felder et al., 2009), 0-68 m.

\section{Family Lysmatidae Dana, 1852}

\section{Lysmata ankeri Rhyne and Lin, 2006}

Previous records. Abele and Kim, 1989: 19 [Gatun Locks, as Lysmata. wurdemanni (Gibbes, 1850)]; Rhyne and Lin, 2006: 179 [Caribbean Panama].

Remarks. Rhyne and Lin (2006) referred part of the material of L. wurdemanni in Abele and Kim (1989) to L. ankeri, however, without any further comments. 
The material in Abele and Kim (1989) included two specimens ( 1 male and 1 ovigerous female) collected from the lower western chamber of Gatun Locks. As neither specimen was discussed by Rhyne and Lin (2006), it is unclear which of them is L. ankeri. Based on the species' wide occurrence in the tropical and subtropical western Atlantic, from southern Florida to São Paulo, Brazil (Rhyne and Lin, 2006), its occurrence in Panama is highly likely but does require confirmation.

\section{Lysmata bahia Rhyne and Lin, 2006}

Previous records. Baeza, 2008: 182 [Isla Colón, Bocas del Toro]; Baeza et al., 2009: 417 [Bocas del Toro]; Baeza, 2010: 257 [Bocas del Toro]; Fiedler et al., 2010: 3 [Bocas del Toro].

Material examined. Bocas del Toro. 1 spec., Isla Colón, between STRI station and Playa Bluff, fossil reef terrace, intertidal, at night, leg. A. Baeza, 2007, OUMNH.ZC.2009-06-003; 1 spec. same collection data, OUMNH.ZC.2009-06-008.

Remarks. Curiously, L. bahia is presently only known from Panama and several Brazilian states (Ceará, Sergipe Bahia, São Paulo and Rio de Janeiro) (Barros-Alves et al., 2015); on rocky bottoms and in tide pools, $0-25 \mathrm{~m}$.

\section{Lysmata hochi Baeza and Anker, 2008}

Previous records. Baeza and Anker, 2008: 149 [Isla Colón, Bocas del Toro].

Material examined. Bocas del Toro. $1 \mathrm{spec}$., Isla Colón, Boca del Drago, 09²4.764’N 082¹9.868'W, at night, leg. A. Anker, 05.08.2008, OUMNH. ZC.200814-049.

Remarks. Currently only known from Panama (Bocas del Toro) and Florida (Long Key) (Baeza, 2010); on rocky shores in very shallow water, 0-1 m.

\section{Lysmata intermedia (Kingsley, 1878)}

Previous records. (?) Birkeland et al., 1976: 137 [Galeta reef]; (?) Cubit and Williams, 1983: 25 [Galeta Point]; (?) Abele and Kim, 1989: 19 [Gatun Locks];
(?) Baeza, 2008: 182 [Isla Colón, Bocas del Toro]; (?) Baeza et al., 2009: 417 [Bocas del Toro]; (?) Baeza, 2010: 257 [Bocas del Toro]; (?) Fiedler et al., 2010: 3 [Bocas del Toro].

Material examined. Bocas del Toro. 3 spec., Isla Bastimentos, off Salt Creek, coral rubble on sea grass flat, 1-1.2 m, leg. A. Anker, 31.03.2008, OUMNH. ZC.2012-01-007; 2 spec., same collection data, OUMNH.ZC.2012-01-008.

Remarks. Although the exact distribution of $L$. intermedia is unclear due to confusion with the recently described Lysmata jundalini Rhyne, Calado and dos Santos, 2012 (see below), the species seems to be relatively widespread in the western Atlantic, from Florida to Brazil (Pachelle et al., 2016); typically on rocky and rubble-algal bottoms, 0-22 $\mathrm{m}$. The herein examined specimens were assigned to $L$. intermedia on the basis of their colour pattern and some morphological characteristics listed in Rhyne et al. (2012), although the distinction between preserved L. intermedia and L. jundalini specimens is extremely difficult as most diagnostic characters overlap and are ambiguous. All previous records of L. intermedia from Panama cannot be confirmed at this stage as they could refer to either species.

\section{Lysmata jundalini Rhyne, Calado and dos Santos, 2012}

Previous records. Rhyne et al., 2012: 77 [Caribbean Panama].

Material examined. Bocas del Toro. Many spec., Isla Bastimentos, Cayo Coral (Coral Cay), in old conch shells, leg. C. Tavares, 06.08.2008, OUMNH. ZC.2008-14-134; 2 spec., Isla Bastimentos, Cayo Coral (Coral Cay), near restaurant, $09^{\circ} 14.502^{\prime} \mathrm{N}$ $082^{\circ} 08.288^{\prime} \mathrm{W}$, under rocks and coral rubble, $1 \mathrm{~m}$, leg. A. Anker, 11.08.2008, OUMNH.ZC.2008-14-054; 5 spec., Isla Bastimentos, Cayo Coral (Coral Cay), inside eroded conch shells, less than $0.5 \mathrm{~m}$, leg. A. Anker et al., 19.08.2008, OUMNH.ZC.2012-07-007; 1 spec., Isla San Cristobal, Punta Coco, under rocks and coral rubble, 1-1.5 m, leg. A. Anker, 29.10.2005, OUMNH. ZC.2009-18-045; 1 spec., Isla Colón, between STRI 
station and Playa Bluff, fossil reef terrace, intertidal, leg. A. Baeza, 2007, OUMNH.ZC.2009-06-004.

Remarks. Currently known only from Puerto Rico, Mexico (Alacranes Reef in the southern Gulf of Mexico) and Panama (Bocas del Toro) (Rhyne et al., 2012); on mixed rubble-algal substrates near reefs and sea grass, in old conch shells etc., 0-2 m. The unsubstantiated record from the Caribbean Panama in Rhyne et al. (2012) is based on the herein examined specimens.

\section{Lysmata moorei Rathbun, 1906}

Previous records. Abele, 1976: 273 [around Colón]; Baeza et al., 2009: 417 [Galeta]; Baeza, 2010: 257 [Galeta]; Fielder et al., 2010: 4 [Galeta].

Remarks. Amphi-Atlantic taxon, in the western Atlantic sparsely recorded from Bermuda southwards to Paraíba, Brazil (Anker and Cox, 2011); rocky shores and other hard bottom and reef habitats, in shallow water $(0-5 \mathrm{~m})$.

\section{Family Merguiidae Christoffersen, 1990}

\section{Merguia rhizophorae (Rathbun, 1900)}

Previous records. Abele, 1970: 661 [mangrove area on the Atlantic coast of Panama]; Abele, 1972a: 132 [Caribbean Panama]; Abele, 1976: 268 [around Colón]; Gilchrist et al., 1983: 239 [Galeta Island]; Baeza et al., 2009: 417 [Bocas del Toro]; Baeza, 2010: 257 [Bocas del Toro]; Fiedler et al., 2010: 4 [Bocas del Toro]

Material examined. Bocas del Toro. 2 spec., Isla Colón, between STRI station and Playa Bluff, fossil coral terrace, intertidal, at night, leg. A. Baeza, 2007; OUMNH.ZC.2009-06-005; 2 spec., same location, leg. A. Baeza, 2008, OUMNH.ZC.2010-04-022.

Remarks. Amphi-Atlantic taxon, in the western Atlantic sparsely recorded from Panama southwards to Bahia, Brazil (Almeida et al., 2012); typically around driftwood and between prop roots in supratidal mangrove areas, semi-terrestrial.

\section{Family Ogyrididae Holthuis, 1955}

\section{Ogyrides alphaerostris (Kingsley, 1880)}

Material examined. Colón. 5 spec., Isla Largo, Remo, leg. unknown, 2007, OUMNH.ZC.2009-18-004.

Remarks. Western Atlantic, from Virginia southwards to Rio Grande do Sul, Brazil (Almeida et al., 2013); on a variety of soft sediments, $0-52 \mathrm{~m}$. The present specimens are the first record for Panama.

\section{Family Palaemonidae Rafinesque, 1815}

\section{Ancylomenes pedersoni (Chace, 1958)}

Material examined. Bocas del Toro. 4 spec., Isla San Cristobal, eastern side, Laguna Porras, $09^{\circ} 16.514^{\prime} \mathrm{N}$ $082^{\circ} 14.833^{\prime} \mathrm{W}$, on sea anemone Lebrunia neglecta (Duchassaing and Michelotti, 1860), $7 \mathrm{~m}$, leg. S. De Grave, 02.08.2005, OUMNH.ZC.2005-10-048; 2 spec., Isla Solarte, Hospital Point, 09²0.016’N $082^{\circ} 13.133^{\prime} \mathrm{W}, 15 \mathrm{~m}$, leg. S. De Grave, 08.08.2005, OUMNH.ZC.2005-10-047; 2 spec., same collection data, OUMNH.ZC.2005-10-050; 2 spec., Bahía Almirante, off Isla Colón, $3 \mathrm{~m}$, leg. S. De Grave, 06.08.2005, OUMNH.ZC.2005-10-049.

Remarks. Widely distributed in the western Atlantic, from North Carolina southwards to Espírito Santo, Brazil (Vieira et al., 2012); usually associated with sea anemones between 1 and $40 \mathrm{~m}$; well known as fish cleaner. The present specimens constitute the first record of $A$. pedersoni for Panama.

\section{Ascidonia miserabilis (Holthuis, 1951)}

Previous records. Pachelle et al., 2012: 2 [San Blas Islands].

Remarks. Rarely recorded species, with just a few records in the western Atlantic, ranging from the Flower Garden Banks, Texas, southwards to Atol das Rocas, Brazil (Pachelle et al., 2012); associated with solitary ascidians, $0-30 \mathrm{~m}$.

\section{Brachycarpus biunguiculatus (Lucas, 1846)}

Previous records. Abele, 1976: 273 [around Colón]. 
Material examined. Bocas del Toro. 1 spec., Isla Solarte, Hospital Point, 09²0.016’N 082. '13.113'W, on sponge, $10 \mathrm{~m}$, leg. S. De Grave, 09.08.2005, OUMNH. ZC.2005-10-022; 1 spec., Isla Grande, leg. A. Anker, 2006, OUMNH.ZC.2007-13-016; 1 spec., Isla Colón, Boca del Drago, $09^{\circ} 24.924^{\prime} \mathrm{N} 082^{\circ} 19.824^{\prime} \mathrm{W}$, inside eroded conch, leg. A. Anker, 10.08.2008, OUMNH. ZC.2008-14-038; 1 spec., Isla Colón, Puss Head Point, $09^{\circ} 21.802^{\prime} \mathrm{N} 082^{\circ} 14.333^{\prime} \mathrm{W}$, under ledge, $1 \mathrm{~m}$, leg. J.F. Lazarus, 08.08.2008, OUMNH.ZC.2008-14-068.

Remarks. Pantropical taxon, also occurring in temperate regions such as the Mediterranean Sea; in the western Atlantic recorded from North Carolina southwards to Espírito Santo, Brazil (Ferreira et al., 2010); found in a wide variety of habitats, from the intertidal to just over $100 \mathrm{~m}$.

\section{Cuapetes americanus (Kingsley, 1878)}

Previous records. Birkeland et al., 1976: 135 [Galeta reef, as Periclimenes americanus]; Heck, 1977: 338 [around Galeta Island, as P. americanus]; Heck, 1979: 198 [Caribbean Panama, as P. americanus]; Cubit and Williams, 1983: 25 [Galeta Point, as P. americanus].

Material examined. Bocas del Toro. 1 spec., Isla Carenero, Buccaneer, from burrows, $0.5-1.0 \mathrm{~m}$, leg. A. Anker and A. Baeza, 14.10.2006, OUMNH. ZC.2007-13-009; 1 spec., Isla Solarte, Hospital Point, $09^{\circ} 20.016^{\prime} \mathrm{N} 082^{\circ} 13.133^{\prime} \mathrm{W}$, in Halimeda clumps, depth: 4 m, leg. S. De Grave, 09.08.2005, OUMNH.ZC.200510-046; 3 spec., Isla Colón, STRI pier, $09^{\circ} 14.983^{\prime} \mathrm{N}$ $082^{\circ} 08.239^{\prime} \mathrm{W}$, sledge over sea grass bed, 1-2 m, leg. S. De Grave, 06.08.2008, OUMNH.ZC.2008-14032; 3 spec., Isla Colón, STRI Point, $09^{\circ} 20.927^{\prime} \mathrm{N}$ $082^{\circ} 15.808^{\prime} \mathrm{W}$, coral rubble, $17 \mathrm{~m}$, leg. S. De Grave, 10.08.2005, OUMNH.ZC.2005-10-039; 3 spec., Isla Colón, Boca del Drago, coral rocks, $1 \mathrm{~m}$, leg. A. Anker, 11.11.2006, OUMNH.ZC.2007-13-004; 1 spec., Isla Colón, STRI Point, 09²0.927’N 082¹5.808’W, coral rubble, $20 \mathrm{~m}$, leg. S. De Grave, 07.08.2005, OUMNH.ZC.2005-10-037; 4 spec., Isla Colón, west of Punta Caracol, $09^{\circ} 22.410^{\prime} \mathrm{N} 082^{\circ} 17.887^{\prime} \mathrm{W}$, on sponge Tedania (Tedania) cf. ignis (Duchaissang and Michelotti, 1864), 1 m, leg. S. De Grave, 13.08.2008, OUMNH.ZC.2008-14-025; 1 spec., Isla San Cristobal, east of mouth of Pigeon Creek, in Halimeda clumps, 1 $\mathrm{m}$, leg. T. Haney, 09.08.2005, OUMNH.ZC.2005-10044; 1 spec., Isla Colón, Boca del Drago, NE of Lime Point, $09^{\circ} 24.954^{\prime} \mathrm{N} 082^{\circ} 19.757^{\prime} \mathrm{W}$, in sea grass bed, 1 $\mathrm{m}$, leg. S. De Grave, 05.08.2005, OUMNH.ZC.200510-045; 3 spec., Isla Colón, Boca del Drago, leg. S. Le Croy, 03.08.2005, OUMNH.ZC.2005-10-035; 1 spec., Isla Colón, Boca del Drago, coral rocks, $0.5-1.0 \mathrm{~m}$, leg. A. Anker, 20.10.2005, OUMNH.ZC.2007-13-006; 2 spec., Isla Colón, near STRI station, off NOAA beacon, $09^{\circ} 14.983^{\prime} \mathrm{N} 082^{\circ} 08.239^{\prime} \mathrm{W}$, overnight light trap, 3 $\mathrm{m}$, leg. S. De Grave, 03.08.2005, OUMNH.ZC.200510-036; 8 spec., Isla San Cristobal, Pigeon Creek, in Caulerpa verticillata on red mangrove prop roots, 0.5 m, leg. S. LeCroy, 08.2005, OUMNH.ZC.2005-10043; 4 spec., Bocas del Toro, Isla Solarte, Hospital Point, $09^{\circ} 20.016^{\prime} \mathrm{N} 082^{\circ} 13.133^{\prime} \mathrm{W}$, in coral rubble, $3 \mathrm{~m}$, leg. S. De Grave, 06.08.2005, OUMNH.ZC.2005-10042; 1 spec., Isla Solarte, Hospital Point, $09^{\circ} 20.016^{\prime} \mathrm{N}$ $082^{\circ} 13.133^{\prime} \mathrm{W}$, on sponge Niphates erecta, $15 \mathrm{~m}$, leg. S. De Grave, 06.08.2005, OUMNH.ZC.2005-10-040; 3 spec., channel between Isla Bastimentos and Isla Solarte (Hospital Bight), 09¹8.269’N 082 ${ }^{\circ} 10.339^{\prime} W$, leg. S. LeCroy, 06.08.2005, OUMNH.ZC.2005-10-041.

Remarks. Common and widely recorded western Atlantic shrimp, ranging from North Carolina southwards to São Paulo (Brazil), including much of the Caribbean Sea and Gulf of Mexico (Vieira et al., 2012); occurs in a wide variety of habitats, intertidal to $73 \mathrm{~m}$.

\section{Gnathophylloides mineri Schmitt, 1933}

(Fig. 1D)

Material examined. San Blas Islands. $1 \mathrm{spec} .$, Isla Diablo (small uninhabited island near Cartí), reef flat with abundant rubble and some sea grass, associated with unidentified sea urchin, 1-2 m, leg. A. Anker and I. Marin, 23.05.2007, OUMNH.ZC.2009-18-033.

Remarks. Pantropical shrimp, in the western Atlantic occurring from Bermuda southwards to Espírito Santo, Brazil (Tavares et al., 2017); associated with a variety of regular sea urchins, $0-10 \mathrm{~m}$. The present material represents the first record of the species for Panama. 


\section{Gnathophyllum americanum Guérin-Méneville, 1855}

Previous records. Birkeland et al., 1976: 135 [Galeta reef]; Cubit and Williams, 1983: 25 [Galeta Point].

Material examined. Bocas del Toro. 1 spec., Isla Solarte, Hospital Point, under rubble in shallow water, leg. S. De Grave, 04.08.2008, OUMNH.2008-14-027. Isla Grande. 1 spec., under rocks, shallow water, leg. A. Anker, 21.04.2006, OUMNH.ZC.2006-10-010. San Blas Islands. $1 \mathrm{spec}$. Isla Diablo (small uninhabited island near Cartí), reef flat with abundant rubble and some sea grass, under rubble in very shallow water (less than 2 m), leg. A. Anker, 23.05.2007, OUMNH. ZC.2011-02-032.

Remarks. Well-known pantropical species, widely recorded in the western Atlantic from Bermuda southwards to Bahia, Brazil (Tavares et al., 2017); occurs in a wide variety of habitats, typically close to coral reefs, $0-50 \mathrm{~m}$.

\section{Holthuisaeus bermudensis (Armstrong, 1940)}

Previous records. Anker and De Grave, 2010: 119 [Isla Solarte, Bocas del Toro].

Remarks. Widely distributed but rather uncommon western Atlantic species, ranging from Bermuda southwards to Espírito Santo, Brazil, with a few scattered records from the Caribbean Sea and Gulf of Mexico; formerly known as Periclimenaeus bermudensis (see Anker and De Grave, 2010); associated with a variety of sponge species, $15-78 \mathrm{~m}$.

\section{Leander tenuicornis (Say, 1818)}

Previous records. Holthuis, 1952: 161 [Caledonia Bay]; Heck, 1977: 338 [around Galeta Island]; Heck, 1979: 199 [Caribbean Panama].

Material examined. Bocas del Toro. 1 spec., Punta Manglar, $09^{\circ} 19.836^{\prime} \mathrm{N} 082^{\circ} 15.060^{\prime} \mathrm{W}$, muddy sea grass bed, sweep net, $0.5 \mathrm{~m}$, leg. S. De Grave, 13.08.2008, OUMNH.ZC. 2008-14-033; 3 spec., Isla Colón, Boca del Drago, intertidal and shallow subtidal, near sea grass, at night, $09^{\circ} 24.764^{\prime} \mathrm{N} 082^{\circ} 19.868^{\prime} \mathrm{W}$, leg. A. Anker, 05.08.2008, OUMNH.ZC.2008-14-034; 1 spec., same collection data, OUMNH. ZC.2008-14-035; 1 spec., Isla Colón, Boca del Drago, 09²4.764’N 082 $19.868^{\prime} \mathrm{W}$, sea grass bed, leg. S. De Grave, 05.08.2008, OUMNH. ZC.2008-14-066, 2 spec., Isla Colón, Boca del Drago, $09^{\circ} 24.924^{\prime} \mathrm{N} 082^{\circ} 19.834^{\prime} \mathrm{W}$, sea grass bed, leg. S. De Grave, 04.08.2008, OUMNH.ZC.2008-14-067; 1 spec., Isla Carenero, $09^{\circ} 20.675^{\prime} \mathrm{N} 082^{\circ} 13.762^{\prime} \mathrm{W}$, sea grass bed, leg. J. Jurovich, 06.08.2008, OUMNH. ZC.2008-14-036. Isla Grande. 1 spec., southern shore, sea grass with rubble, less than $1 \mathrm{~m}$, leg. A. Anker, 2007, OUMNH.ZC.2009-18-015.

Remarks. Pantropical shrimp, occasionally extending into temperate and even cool waters; in the western Atlantic recorded from Newfoundland southwards to the Falkland Islands (Ferreira et al., 2010); typically associated with algae and sea grass, $0-10 \mathrm{~m}$.

\section{Neopontonides beaufortensis (Borradaile, 1920)}

Previous records. Holthuis, 1951: 192 [Caledonia Bay].

Remarks. It remains unclear if this species actually occurs in the Caribbean Sea or is replaced here by the related Neopontonides chacei Heard, 1986 (see below).

\section{Neopontonides brucei Fransen and Almeida, 2009}

Previous records. Fransen and Almeida, 2009: 838 [Swan Cay, Bocas del Toro].

Remarks. Currently known only from Bahia and São Paulo in Brazil, as well as the Caribbean coast of Panama (based on a single record) (Fransen and Almeida, 2009); presumably associated with gorgonians, 1-32 $\mathrm{m}$.

\section{Neopontonides chacei Heard, 1986}

Material examined. Bocas del Toro. 5 spec., Hospital Point, $09^{\circ} 20.016^{\prime} \mathrm{N} 082^{\circ} 13.133^{\prime} \mathrm{W}, 10 \mathrm{~m}$, on unidentified gorgonian, leg. S. De Grave and M. Salazar, 09.08.2005, OUMNH.ZC.2005-10-099; 4 spec., Isla Bastimentos, offshore reef near Cayo Coral 
(Coral Cay), Archipelago, $09^{\circ} 13.433^{\prime} \mathrm{N} 082^{\circ} 06.180^{\prime} \mathrm{W}$, on Plexaurella sp., 1-2 m, leg. S. De Grave, 11.08.2008, OUMNH.ZC.2008-14-138; 1 spec., same collection data, OUMNH.ZC.2008-14-145.

Remarks. Sparsely recorded in the tropical northwestern Atlantic, from the Florida Keys southwards to Belize (Wicksten and Cox, 2011), and now Panama; usually associated with Antillogorgia americana, but also recorded from Leptogorgia sp. (Wicksten and Cox, 2011) and now from Plexaurella sp., $1-10 \mathrm{~m}$.

\section{Palaemon northropi (Rankin, 1898)}

Previous records. Holthuis, 1952: 195 [near Colón]; Ashelby et al., 2012: 295 [Bocas del Toro].

Material examined. Bocas del Toro. 1 spec., Isla Colón, near Playa Bluff, leg. A. Anker, 13.10.2006, OUMNH.ZC.2007-13-011; 1 spec., Isla Colón, STRI pier, $09^{\circ} 14.983^{\prime} \mathrm{N} 082^{\circ} 08.239^{\prime} \mathrm{W}$, under pier, leg. S. De Grave, 05.08.2008, OUMNH.ZC.2008-14-031; many spec., same location, leg. C. Ashelby, 08.08.2008, OUMNH.ZC.2008-14-129.

Remarks. Common and widely distributed western Atlantic palaemonid, ranging from Bermuda southwards to Uruguay (Ferreira et al., 2010); occurs in a wide range of habitats from the intertidal to about $5 \mathrm{~m}$.

\section{Periclimenaeus caraibicus Holthuis, 1951}

Previous records. Duffy, 1992: 131 [San Blas Islands].

Material examined. Bocas del Toro. $1 \mathrm{spec}$. Isla Colón, STRI pier, in unidentified sponge, leg. C. Ashelby, 06.08.2008, OUMNH.ZC.2008-14-130; 1 spec., Isla Colón, west of Punta Caracol, 09²2.410’ N $082^{\circ} 17.887^{\prime} \mathrm{W}$, in unidentified sponge, $1 \mathrm{~m}$, leg. $\mathrm{L}$. Anderson, 13.08.2008, OUMNH.ZC.2008-14-065; 1 spec., Swan Cay, 09²7.200’N 082 ${ }^{\circ} 17.900^{\prime} W$, on gorgonian Pseudaxinella sp., $3 \mathrm{~m}$, leg. S. De Grave, 04.08.2005, OUMNH.ZC.2005-10-034; 1 spec., same collection data, OUMNH.ZC.2005-10-033; 1 spec., Bocas del Toro, Isla Solarte, Hospital Point, $09^{\circ} 19.996^{\prime} \mathrm{N} 082^{\circ} 13.161^{\prime} \mathrm{W}$, in sponge Tedania cf. ignis, leg. S. De Grave, 04.08.2008, OUMNH.ZC.2008-14072; 1 spec., same collection data, OUMNH.ZC.200814-073; 1 spec., same collection data, OUMNH. ZC.2008-14-140.

Remarks. Sparsely distributed in the western Atlantic, from Cuba southwards to Rio Grande do Norte, Brazil (Vieira et al., 2012); recorded from a variety of habitats in older literature, but appears to be an obligate sponge associate, $0-3 \mathrm{~m}$.

\section{Periclimenaeus perlatus (Boone, 1930)}

Previous records. Holthuis, 1951: 102 [Caledonia Bay].

Remarks. Sparsely recorded in the western Atlantic, from the Dry Tortugas southwards to Pernambuco, Brazil (Vieira et al., 2012); an obligate sponge associate, 0-37 m.

\section{Periclimenaeus schmitti Holthuis, 1951}

Material examined. Bocas del Toro. 5 spec., Isla Colón, west of Punta Caracol, 09²2.410’N $082^{\circ} 17.887^{\prime} \mathrm{W}$, in sponge Lissodendoryx colombiensis, 1 m, leg. S. De Grave, 07.08.2008, OUMNH.ZC.2008-14071; 1 spec., same collection data, OUMNH.ZC.200814-069; 1 spec., same collection data, OUMNH.ZC. 2008-14-070; 3 spec., same collection data, leg. A. Anker, 07.08.2008, OUMNH.ZC.2008-14-064; 1 spec., Isla Colón, STRI Bay, in sponge Xestospongia rosariensis, leg. E. Tóth, 29.09.2006, OUMNH.ZC.2007-13001 ; 2 spec., Almirante, in sponge L. colombiensis, leg. E. Tóth, 04.01.2007, OUMNH.ZC.2007-14002; 1 spec., Isla Colón, STRI Bay, in unidentified sponge growing on mangrove roots, leg. J.F. Lazarus, 09.08.2008, OUMNH.ZC.2008-14-137; 1 spec., Isla Colón, STRI pier, $09^{\circ} 14.983^{\prime} \mathrm{N} 082^{\circ} 08.239^{\prime} \mathrm{W}$, in unidentified sponge, leg. S. De Grave, 05.08.2008, OUMNH.ZC.2008-14-139; 3 spec., Isla Colón, west of Punta Caracol, $09^{\circ} 22.410^{\prime} \mathrm{N} 082^{\circ} 17.887^{\prime} \mathrm{W}$, in sponge Monanchora arbuscula (Duchassaing and Michelotti, 1864), 1 m, leg. S. De Grave, 11.08.2008, OUMNH. ZC.2008-14-063; 1 spec., Isla Colón, Puss Head Point, in sponge L. colombiensis, leg. C. Ashelby, 08.08.2008, OUMNH. ZC.2008-14-128. 
Remarks. Previously known only from North Carolina, the Dry Tortugas and the southern Gulf of Mexico (Santana-Moreno et al., 2013), now reported for the first time from Panama and the Caribbean Sea [although the colour photograph in De Grave and Fransen (2011, p. 359) refers to OUMNH.ZC.200814-064, which was also referenced in Santana-Moreno et al. (2013)]; associated with various sponges, 0-20 m.

\section{Periclimenes antipathophilus Spotte, Heard and Bubucis, 1994}

Material examined. Bocas del Toro. 9 spec., Isla Solarte, Hospital Point, 09²0.016’ N 082 $13.133^{\prime}$ W, on unidentified black coral, $15 \mathrm{~m}$, leg. S. De Grave and M. Salazar, 08.08.2005, OUMNH.ZC.2016-01-067.

Remarks. Uncommon species; currently known from the north-eastern Gulf of Mexico, the Turks and Caicos Islands, Honduras (Bay Islands) (Wicksten et al., 2014), and now also Panama; obligatory associate of black corals, recorded as an associate on two Stichopathes Brook, 1889 species and possibly Acanthopathes thyoides (Pourtalès, 1880) (see Wicksten et al., 2014), 15-45 m.

\section{Periclimenes colesi De Grave and Anker, 2009}

Material examined. Bocas del Toro. 8 spec., Isla Solarte, Hospital Point, 09²0.016'N 082 ${ }^{\circ} 13.133^{\prime}$ W, in sponge Mycale laxissima, $15 \mathrm{~m}$, leg. S. De Grave and M. Salazar, 08.08.2005, OUMNH.ZC.2016-01-068; 10 spec., same location, in sponge Xestospongia rosariensis, $15 \mathrm{~m}$, leg. S. De Grave and M. Salazar, 06.08.2005, OUMNH.ZC.2016-01-069; 4 spec., Isla Bastimentos, Cayo Coral (Coral Cay), 09¹5.028’ N 08207.897’W, in unidentified sponge, $10 \mathrm{~m}$, leg. S. De Grave and M. Salazar, 07.08.2005, OUMNH.ZC.2016-01-070; 8 spec., same collection data, OUMNH.ZC.201601-071; 2 spec., Isla Colón, STRI pier, 09¹4.983’N $082^{\circ} 08.239^{\prime} \mathrm{W}$, in sponge Niphates erecta, leg. S. De Grave, 05.08.2008, OUMNH.ZC.2016-01-072.

Remarks. Known with certainty only from the type locality in Honduras (Bay Islands) (De Grave and Anker, 2009) and now Panama (Bocas del Toro); likely to be the senior synonym of Periclimenes sandyi De
Grave, 2009 (S. De Grave, pers. obs.); associated with a variety of sponges, $0-15 \mathrm{~m}$.

\section{Periclimenes mclellandi Heard and Spotte, 1997}

Material examined. Bocas del Toro. 1 spec., Isla Bastimentos, Cayo Coral, $09^{\circ} 14.502^{\prime} \mathrm{N}$ 082 08.288'W, on gorgonian Plexaurella cf. grandiflora Verrill, 1912, 1 m, leg. S. De Grave, 13.08.2008, OUMNH.ZC.201601-073; 2 spec., same collection data, OUMNH. ZC.2016-01-074; 2 spec., Isla Bastimentos, offshore reef near Cayo Coral, $09^{\circ} 13.433^{\prime} \mathrm{N}$ 082 $2^{\circ} 06.180^{\prime} \mathrm{W}$, on gorgonian Antillogorgia americana, 1-2 m, leg. S. De Grave, 11.08.2008, OUMNH.ZC.2016-01-075; 3 spec., Isla Colón, west of Punta Caracol, 09²2.410’ N $082^{\circ} 17.887^{\prime} \mathrm{W}$, on $A$. americana, $1 \mathrm{~m}$, leg. S. De Grave, 11.08.2008, OUMNH.ZC.2016-01-076; 1 spec., Isla Colón, STRI pier, $09^{\circ} 14.983^{\prime} \mathrm{N} 082^{\circ} 08.239^{\prime} \mathrm{W}$, on unidentified sponge, leg. S. De Grave, 05.08.2008, OUMNH.ZC.2016-01-077; 8 spec., Isla San Cristobal, Punta Coco, $09^{\circ} 18.070^{\prime} \mathrm{N} 082^{\circ} 17.661^{\prime} \mathrm{W}$, on $A$. americana, leg. S. De Grave, 14.08.2008, OUMNH. ZC.2016-01-078.

Remarks. Known with certainty only from the type locality in the Turks and Caicos Islands (Heard and Spotte, 1997) and now Panama (Bocas del Toro); associated with a variety of shallow-water gorgonians, although primarily with $A$. americana, 1-43 m.

\section{Periclimenes patae Heard and Spotte, 1991}

Material examined. Bocas del Toro. 1 spec., Isla San Cristobal, Punta Coco, $09^{\circ} 18.070$ 'N 082 $2^{\circ} 17.661^{\prime} \mathrm{W}$, on gorgonian Plexaurella sp., leg. S. De Grave, 14.08.2008, OUMNH.ZC.2008-14-141.

Remarks. Previously known from the Florida Keys and the Turks and Caicos Islands (Felder et al., 2009) and now Panama (Bocas del Toro); associated with a variety of shallow-water gorgonians, although primarily with Antillogorgia americana, 1-12 m.

\section{Periclimenes pauper Holthuis, 1951}

Material examined. Bocas del Toro. 1 spec., Swan Cay, $09^{\circ} 27.200^{\prime} \mathrm{N} 082^{\circ} 17.900^{\prime} \mathrm{W}$, on black coral 
Antipathes sp., 3 m, leg. S. De Grave, 04.08.2005, OUMNH.ZC.2005-10-051.

Remarks. Our single specimen from Swan Cay has no antennal tooth and thus corresponds to the diagnosis of P. pauper in Holthuis (1951), although it has a strong morphological similarity to the members of the Periclimenes iridescens (Lebour, 1949) species complex. It seems probable that this taxon was based on aberrant specimens of the P. iridescens complex and will need to be taxonomically reassessed. It was previously recorded from Venezuela and Curaçao (Criales, 1980), and now for the first time from Panama.

\section{Periclimenes perryae Chace, 1942}

Previous record: Felder et al., 2009: 1090 [Caribbean Panama].

Material examined. Bocas del Toro. 1 spec., Isla San Cristobal, eastern side, Laguna Porras, $09^{\circ} 17.342^{\prime} \mathrm{N}$ $082^{\circ} 15.384^{\prime} \mathrm{W}$, on basket star Astrophyton muricatum (Lamarck, 1816), 7 m, leg. S. De Grave, 03.08.2005, OUMNH.ZC.2005-10-056.

Remarks. Previously recorded from Florida and Colombia (Felder et al., 2009); the unsubstantiated record from the Caribbean coast of Panama in Felder $e t$ al. (2009) refers to the above-listed specimen; obligate associate of the basket star A. muricatum, 0-10 m.

\section{Periclimenes rathbunae Schmitt, 1924}

Material examined. Bocas del Toro. 1 spec., Carenero Island, near Buccaneer, less than $1 \mathrm{~m}$, leg. A. Anker, 04.11.2006, OUMNH.ZC.2007-13-002; 2 spec., Swan Cay, 09²7.200’N 082 ${ }^{\circ} 17.900^{\prime} W$, on sea anemone Actinoporus elegans Duchassaing, 1850, $3 \mathrm{~m}$, leg. S. De Grave, 04.08.2005, OUMNH.ZC.2005-10055. Isla Grande. 2 spec., leg. unknown, 15.06.1995, OUMNH.ZC.2009-18-001. San Blas Islands. 1 spec., near Cartí, leg. I. Marin and A. Anker, 23.05.2007, OUMNH.ZC.2009-18-032.

Remarks. Relatively common in the tropical northwestern Atlantic, from the Dry Tortugas in Florida southwards (Brinkmann and Fransen, 2016) to Panama (new record); typically associated with sea anemones,
0-3 $\mathrm{m}$, but also the coral Dendrogyra cylindricus Ehrenberg, 1834 (see Brinkmann and Fransen, 2016).

\section{Periclimenes sandyi De Grave, 2009}

Previous records. (?) Duffy, 1992: 131 [San Blas Islands, as P. iridescens]; De Grave, 2009: 830 [Bocas del Toro].

Remarks. Known with certainty from Panama (Bocas del Toro, San Blas Islands) and Mexico (Alacranes Reef, Gulf of Mexico) (Santana-Moreno et al., 2013); associated with sponges, $1-10 \mathrm{~m}$. This species is most likely a junior synonym of $P$. colesi (see above).

\section{Periclimenes yucatanicus (Ives, 1891)}

(Fig. 1E)

Previous records. McKeon and O'Donnell, 2015: 2 [Bocas del Toro].

Material examined. Bocas del Toro. 1 spec., Isla Solarte, Hospital Point, 09 $19.996^{\prime} \mathrm{N} 082^{\circ} 13.161^{\prime} \mathrm{W}$, among shallow rubble, leg. S. De Grave, 04.08.2008, OUMNH.ZC.2008-14-029; 6 spec., Isla San Cristobal, eastern side, Laguna Porras, $09^{\circ} 16.514^{\prime} \mathrm{N}$ $082^{\circ} 14.833^{\prime} \mathrm{W}$, on sea anemone Actinoporus elegans, 7 m, leg. S. De Grave, 02.08.2005, OUMNH.ZC.200510-054; 2 spec., same location, on unidentified corallimorpharian, $7 \mathrm{~m}$, leg. S. De Grave, 03.08.2005, OUMNH.ZC.2005-10-052; 1 spec., off Isla Colón, Bahía Almirante, 3 m, leg. S. De Grave, 06.08.2005, OUMNH.ZC.2005-10-053; 1 spec., Isla Colón, off STRI pier, $09^{\circ} 14.983^{\prime} \mathrm{N} 082^{\circ} 08.239^{\prime} \mathrm{W}$, in sea grass bed, sledge, leg. S. De Grave, 06.08.2008, OUMNH. ZC.2008-14-144; 1 spec., Isla Colón, near STRI station, on unidentified anemone on mangrove root, leg. A. Anker, 29.10.2005, OUMNH.ZC.2007-13-005.

Remarks. Widely distributed in the western Atlantic, from Florida southwards to Espírito Santo, Brazil (Vieira et al., 2012); associated with sea anemones and anemone-like corallimorpharians (carpet anemones); well-known fish cleaner, 0-9 m.

\section{Pontonia mexicana Guérin-Méneville, 1855}

Material examined. Bocas del Toro. 2 spec., Cayo 
Coral (Coral Cay), near restaurant, $09^{\circ} 14.502^{\prime} \mathrm{N}$ 082 08.288’W, in Pinna carnea Gmelin, 1791, $1 \mathrm{~m}$, leg. A. Anker, 11.08.2008, OUMNH.ZC.2008-14-062.

Remarks. Widely distributed in the western Atlantic, ranging from Florida southwards to Ilha de Trindade, Brazil (Fransen, 2002; Tavares et al., 2017); inhabiting several species of large bivalves, $0-2 \mathrm{~m}$; first record for Panama.

\section{Pseudocoutierea dotae De Grave, 2007}

Previous records. De Grave, 2007: 30 [Isla Solarte, Bocas del Toro].

Material examined. Portobelo. 3 spec., Portobelo Bay, on Stichopathes lutkeni Brook, 1889, 15-20 m, leg. A. Anker and D. Roche, 21.07.2007, OUMNH. ZC.2015-01-032; 2 spec., same collection data, OUMNH.ZC.2015-01-033; 2 spec., same collection data, OUMNH.ZC.2015-01-034.

Remarks. This species remains known exclusively from the Caribbean coast of Panama (Bocas del Toro and now Portobelo); obligate associate of the whip coral S. lutkeni, 15-20 m.

\section{Tuleariocaris neglecta Chace, 1969}

Previous records. Giribet and Lemer, 2014: 635 [Isla Solarte, Bocas del Toro].

Remarks. Amphi-Atlantic taxon, in the western Atlantic recorded from Florida and the northern Gulf of Mexico southwards to Panama (Giribet and Lemer, 2014); associated with several species of sea urchins, $0-2 \mathrm{~m}$.

\section{Typton carneus Holthuis, 1951}

Material examined. Bocas del Toro. 1 spec., Isla Solarte, Hospital Point, $09^{\circ} 19.996^{\prime} \mathrm{N} 082^{\circ} 13.161^{\prime} \mathrm{W}$, in sponge Tedania cf. ignis, leg. S. De Grave, 04.08.2008, OUMNH.ZC.2008-14-078; 1 spec. Isla Colón, STRI pier, $09^{\circ} 14.983^{\prime} \mathrm{N} 082^{\circ} 08.239^{\prime} \mathrm{W}$, in sponge Tedania (Tedania) cf. klausi Wulff, 2006, leg. J. Luque, 14.08.2008, OUMNH.ZC.2008-14-061.
Remarks. Recorded in the western Atlantic from Florida and Panama (new record) southwards to Pernambuco, Brazil (Vieira et al., 2012); associated with several sponges, $0-73 \mathrm{~m}$.

\section{Urocaris longicaudata Stimpson, 1860}

Previous records. Heck, 1977: 338 [around Galeta Island, as Periclimenes longicaudatus]; Heck, 1979: 199 [Caribbean Panama, as P. longicaudatus].

Material examined. Bocas del Toro. 1 spec., Isla Colón, Punta Manglar, 09¹9.836’N 082¹5.060’W, muddy sea grass bed, sweep net, $1 \mathrm{~m}$, leg. S. De Grave, 04.08.2008, OUMNH.ZC.2008-14-075; 1 spec., same collection data, OUMNH.ZC. 2008-14-074; 4 spec., same collection data, OUMNH.ZC.2008-14-037.

Remarks. Widely recorded from North Carolina southwards to Santa Catarina (Brazil) (Vieira et al., 2012); usually found in sea grass beds, 0-11 m. Recorded in older literature as Periclimenes longicaudatus (see Bruce, 2007).

\section{Family Pasiphaeidae Dana, 1852}

\section{Leptochela serratorbita Spence Bate, 1888}

Material examined. Bocas del Toro. 2 spec., Isla Colón, STRI station, off NOAA beacon, light trap, 3 m, leg. S. De Grave, 03.08.2005, OUMNH. ZC.2005-10-076; 1 spec., Isla Colón, off STRI pier, $09^{\circ} 14.983^{\prime} \mathrm{N} 082^{\circ} 08.239^{\prime} \mathrm{W}$, light trap, $1 \mathrm{~m}$, leg. S. De Grave, 02.08.2005, OUMNH.ZC.2005-10-074; 1 spec., same location, sea grass sweep, $1 \mathrm{~m}$, leg. $\mathrm{S}$. De Grave, 02.08.2005, OUMNH.ZC.2005-10-075; 1 spec., Isla Colón, Punta Caracol, 2 m, leg. A. Anker, 28.04.2007, OUMNH.ZC.2009-18-006.

Remarks. Widely distributed in the western Atlantic, from North Carolina southwards to São Paulo, Brazil, including much of the Caribbean Sea and Gulf of Mexico (Felder et al., 2009); found in a variety of habitats, typically with sandy bottom, nocturnally planktonic, $1-40 \mathrm{~m}$. The present specimens constitute the first record of the species from Panama. 


\section{Family Processidae Ortmann, 1896}

\section{Ambidexter symmetricus Manning and Chace, 1971}

Previous records. Abele, 1972b: 366 [Galeta Island]; Birkeland et al., 1976: 138 [Galeta reef]; Heck, 1977: 344 [around Galeta Island]; Heck, 1979: 200 [Caribbean Panama]; Cubit and Williams, 1983: 25 [Galeta Point].

Material examined. Bocas del Toro. 1 spec., Isla Carenero, Buccaneer, sea grass with large sand patches, in burrow, 0.5-1.0 m, leg. A. Anker and A. Baeza, 14.10.20006, OUMNH.ZC.2007-13-010; 1 spec., Isla Colón, Boca del Drago, sand with sea grass, less than $1 \mathrm{~m}$, leg. A. Anker et al., 29.04.2007, OUMNH. ZC.2009-18-005. Isla Grande. 1 spec., southwestern shore, in burrow, 0.5-1.5 m, leg. A. Anker, 22.04.2006, OUMNH.ZC.2006-10-007.

Remarks. Widely distributed, although relatively rarely collected western Atlantic shrimp, ranging from Florida southwards to Santa Catarina (Brazil) (Almeida and Bezerra, 2011); primarily found in sea grass habitats, $0-6 \mathrm{~m}$.

\section{Nikoides schmitti Manning and Chace, 1971}

Previous records. Heck, 1977: 377 [around Galeta Island]; Heck, 1979: 199 [Caribbean Panama].

Remarks. Widely distributed in the western Atlantic, from North Carolina southwards to Bahia, Brazil (Almeida and Bezerra, 2011); occurs in a variety of habitats, most abundant in sea grass beds, $0-49 \mathrm{~m}$.

\section{Processa bermudensis (Rankin, 1900)}

Previous records. Birkeland et al., 1976: 138 [Galeta reef]; Cubit and Williams, 1983: 25 [Galeta Point]; De Grave and Felder, 2012: 50 [Caribbean Panama].

Material examined. Bocas del Toro. many spec., Isla Colón, off STRI pier, 09¹4.983’N 08208.239’W, sea grass bed, at night, epibentic sledge, $1 \mathrm{~m}$, leg. $\mathrm{S}$. De Grave et al., 03.08.2005, OUMNH.ZC.2005-10007; 15 spec., same location and collection method,
07.08.2005, OUMNH.ZC.2005-10-004; 1 spec., same location and collection method, 07.08.2005, OUMNH. ZC.2005-10-005; 1 spec., same location and collection method, 02.08.2005, OUMNH.ZC.2005-10-006; 3 spec., Isla Colón, STRI station, off NOAA beacon, $09^{\circ} 14.983^{\prime} \mathrm{N} 082^{\circ} 08.239^{\prime} \mathrm{W}$, nocturnal light trap, 3 $\mathrm{m}$, leg. S. De Grave, 07.08.2005, OUMNH.ZC.200510-008; 2 spec., Isla Carenero, Buccaneer, sea grass flat, in burrow, 0.5-1.0 m, leg. A. Anker and A. Baeza, 14.10.2006, OUMNH.ZC.2007-13-008; 1 spec., Isla Colón, Boca del Drago, 09²4.764’N 082¹9.868’W, shallow subtidal sea grass / sand flat, at night, leg. A. Anker et al., 05.08.2008, OUMNH.ZC.2008-14-059.

Remarks. Widely distributed in the western Atlantic, ranging from North Carolina southwards to Paraná, Brazil (Almeida and Bezerra, 2011); found in a variety of habitats, most common in sea grass beds, $2-45 \mathrm{~m}$.

\section{Processa fimbriata Manning and Chace, 1971}

Previous records. Birkeland et al., 1976: 138 [Galeta reef]; Heck, 1977: 338 [around Galeta Island]; Heck, 1979: 199 [Caribbean Panama]; Cubit and Williams, 1983: 25 [Galeta Point].

Material examined. Bocas del Toro. 3 spec., Swan Cay, $09^{\circ} 27.200^{\prime} \mathrm{N} 082^{\circ} 17.900$ 'W, in coral rubble, 3 $\mathrm{m}$, leg. S. De Grave, 04.08.2005, OUMNH.ZC.200510-003; 1 spec., same location, on sponge Ircinia strobilina, leg. S. De Grave, 04.08.2005, OUMNH. ZC.2005-10-001; 1 spec., same location, on sponge Dragmacidon reticulatum (Ridley and Dendy, 1886) (?), 3 m, leg. S. De Grave, 04.08.2005, OUMNH. ZC.2005-10-002; 2 spec., Isla Colón, west of Punta Caracol, 09²2.410’N 082 $17.887^{\prime}$ W, leg. S. De Grave, 11.08.2005, OUMNH.ZC.2005-10-058; 1 spec., Isla Colón, Boca del Drago, 09²4.764’N 082¹9.868’W, shallow subtidal sea grass/sand flat, at night, leg. A. Anker et al., 05.08.2008, OUMNH.ZC.2008-14-055; 1 spec., same collection data, OUMNH.ZC.2008-14056; 1 spec., same collection data, OUMNH.ZC.200814-048; 2 spec., Isla Colón, west of Punta Caracol, $09^{\circ} 22.410^{\prime} \mathrm{N} 082^{\circ} 17.887^{\prime} \mathrm{W}$, on sponge Ircinia sp., $1 \mathrm{~m}$, leg. S. De Grave, 11.08.2008, OUMNH.ZC.2008-14058; 1 spec., Isla Solarte, Hospital Point, $09^{\circ} 19.996^{\prime} \mathrm{N}$ $082^{\circ} 13.161^{\prime} \mathrm{W}$, shallow coral rubble, leg. S. De Grave et al., 04.08.2008, OUMNH.ZC.2008-14-057; 1 spec., Isla Bastimentos, Playa Wizard, in coral rocks, 0.5-1.0 
m, leg. A. Anker, 21.10.2005, OUMNH.ZC.200713-007. Isla Grande. 1 spec., southwestern shore, under rocks, less than $1 \mathrm{~m}$, leg. A. Anker, 21.04.2006, OUMNH.ZC.2006-10-009.

Remarks. Widely distributed in the western Atlantic, ranging from North Carolina and the northern Gulf of Mexico southwards to Atol das Rocas and Rio de Janeiro, Brazil (Almeida and Bezerra, 2011); recorded from various substrates, commonly foraging in sea grass beds at night and hiding in sponges and coral rubble during the day, 0-50 $\mathrm{m}$.

\section{Processa sp. aff. hemphilli Manning and Chace, 1971}

Previous records. Cubit and Williams, 1983: 25 [Galeta Point].

Remarks. Cubit and Williams (1983) mention this taxon on the basis of a record in an unpublished $\mathrm{PhD}$ thesis. It remains unclear what species this record may refer to.

\section{Family Thoridae Kingsley, 1879}

\section{Thor amboinensis (De Man, 1888)}

Material examined. Bocas del Toro. 1 spec., Swan Cay, $09^{\circ} 27.200^{\prime} \mathrm{N} 082^{\circ} 17.900^{\prime} \mathrm{W}$, on sea anemone Actinoporus elegans, leg. S. De Grave, 04.08.2005, OUMNH.ZC.2005-10-017.

Remarks. Circum-tropical taxon, in the western Atlantic recorded from Bermuda and the northern Gulf of Mexico southwards to at least Fernando de Noronha, Brazil (Felder et al., 2009). Although recorded from the Pacific coast of Panama by Abele (1976), the herein studied material represents the first record of T. amboinensis for the Caribbean coast of Panama. The species is usually found in close proximity to sea anemones and other cnidarians, at depths of about $0-10 \mathrm{~m}$.

\section{Thor floridanus Kingsley, 1878}

Previous records. (?) Heck, 1977: 338 [around Galeta Island]; (?) Heck, 1979: 199 [Caribbean Panama].
Remarks. Heck (1977; 1979) records this species in his seagrass studies, whilst recording the related Thor manningi Chace, 1972 in other work (e.g. Heck and Wetstone, 1977). Whilst it seems highly likely that only one species is involved, it cannot be discounted that both species occur in Panama. Thor floridanus is widespread in the western Atlantic, from North Carolina and the northern Gulf of Mexico southwards to Costa Rica (Felder et al., 2009); most often on seagrass and algae, 0-59 m.

\section{Thor manningi Chace, 1972}

Previous records. Birkeland et al., 1976: 138 [Galeta reef]; (?) Heck, 1977: 338 [around Galeta Island]; Heck and Wetstone, 1977: 200 [around Galeta]; (?) Heck, 1979: 199 [Caribbean Panama]; Cubit and Williams, 1983: 25 [Galeta Point].

Material examined. Bocas del Toro. 8 spec., Isla Bastimentos, Cayo Coral, 09 15.028'N 082 07.897’W, coral rubble, $4 \mathrm{~m}$, leg. S. De Grave, 07.08.2005, OUMNH.ZC.2005-10-012; 4 spec., reef east of mouth of Pigeon Creek, in Halimeda clumps, $1 \mathrm{~m}$, leg. T. Haney, 09.08.2005, OUMNH.ZC.2005-10-013; many spec., Isla Carenero, northern side, $09^{\circ} 20.675^{\prime} \mathrm{N}$ $082^{\circ} 13.762^{\prime} \mathrm{W}$, coral rubble, $0.5 \mathrm{~m}$, leg. S. De Grave, 06.08.2008, OUMNH.ZC.2008-14-077; 2 spec., same collection data, OUMNH.ZC.2008-14-0039; 2 spec., Swan Cay, 09²7.200’N 082 ${ }^{\circ} 17.900^{\prime} W$, coral rubble, 3 m, leg. S. De Grave, 04.08.2005, OUMNH. ZC.2005-10-011; 10 spec., Isla Solarte, Hospital Point, $09^{\circ} 20.016^{\prime} \mathrm{N} 082^{\circ} 13.133^{\prime} \mathrm{W}$, coral rubble, $3 \mathrm{~m}$, leg. S. De Grave, 06.08.2005, OUMNH.ZC.2005-10-009; many spec., same collection data, OUMNH.ZC. 2005-10-015; 2 spec., Isla Colón, Boca del Drago, $09^{\circ} 24.764^{\prime} \mathrm{N} 082^{\circ} 19.868^{\prime} \mathrm{W}$, muddy sea grass bed, leg. S. De Grave, 05.08.2008, OUMNH.ZC.2008-14-060; 1 spec., Isla Colón, STRI station, off NOAA beacon, $09^{\circ} 14.983^{\prime} \mathrm{N} 082^{\circ} 08.239^{\prime} \mathrm{W}$, overnight light trap, $3 \mathrm{~m}$, leg. S. De Grave, 03.08.2005, OUMNH.ZC.2005-10014. Isla Grande. 1 spec., western point, coral rocks, 0.5-1.5 m, leg. A. Anker et al., 06.10.2005, OUMNH. ZC.2006-10-008.

Remarks. Widespread in the western Atlantic, ranging from North Carolina southwards to São Paulo, 
Brazil, and extending to Central Atlantic (Manning and Chace, 1990; Felder et al., 2009); on a variety of substrates, most abundant in algae and amongst sea grass, $0-44 \mathrm{~m}$.

\section{Infraorder Stenopodidea Spence Bate, 1888}

\section{Family Stenopodidae Claus, 1872}

\section{Odontozona libertae Gore, 1981}

Material examined. Bocas del Toro. 1 spec., Isla San Cristobal, eastern side, Laguna Porras, $09^{\circ} 17.342^{\prime} \mathrm{N}$ $082^{\circ} 15.384^{\prime} \mathrm{W}$, in coral rubble, $7 \mathrm{~m}$, leg. S. De Grave and M. Salazar, 03.08.2005, OUMNH.ZC.2012-01-001.

Remarks. The present specimen constitutes the first record of $O$. libertae for Panama, with the species previously known only from the Florida Keys and Colombia (Criales, 1997); recorded on various substrates, 7-56 m.

\section{Stenopus hispidus (Olivier, 1811)}

Previous records. Abele, 1976: 273 [around Colón]; Cubit and Williams, 1983: 25 [Galeta Point].

Material examined. Bocas del Toro. 1 spec., Isla Carenero, eastern side, $09^{\circ} 20.675^{\prime} \mathrm{N} 082^{\circ} 13.762^{\prime} \mathrm{W}$, under rocks in shallow water, leg. A. Anker, 06.08.2008, OUMNH.ZC.2008-14-076. Isla Grande. 1 spec., off western point, <1 m, leg. A. Anker, 22.04.2006, OUMNH.ZC.2006-10-005.

Remarks. Pantropical species (Felder et al., 2009), often living in pairs, usually dwelling in crevices on reefs, from 1 to at least $200 \mathrm{~m}$; well-known fish cleaner.

\section{Stenopus scutellatus Rankin, 1898}

(Fig. 1G)

Previous records. Cubit and Williams, 1983: 25 [Galeta Point].

Material examined. Bocas del Toro. 1 spec., Isla Colón, Boca del Drago, 09²4.764’N 082¹9.868’W, under rocks, leg. S. De Grave, 05.08.2008, OUMNH.
ZC.2008-14-047; 2 spec., Isla San Cristobal, Punta Coco, 1-1.5 m, leg. A. Anker, 29.10.2005, OUMNH. ZC.2006-10-006.

Remarks. Common western Atlantic species, distributed from Bermuda across the entire Caribbean and Gulf of Mexico to northern Brazil (Felder et al., 2009), at depths of 1-182 m; well-known fish cleaner, often encountered on or near the barrel sponge, Xestospongia muta (Schmidt, 1870).

\section{Family Spongicolidae Schram, 1986}

\section{Microprosthema semilaeve (von Martens, 1872) (Fig. 1H)}

Previous records. Goy and Martin, 2013: 468 [San Blas Islands; Bocas del Toro]

Material examined. Bocas del Toro. 3 spec., Isla Carenero, Buccaneer, under rocks and coral rubble, 0.5 m, leg. A. Anker, 16.10.2005, OUMNH.ZC.2007-13012 ; 1 spec., Isla Carenero, eastern side, $09^{\circ} 20.675^{\prime} \mathrm{N}$ $082^{\circ} 13.762^{\prime} \mathrm{W}$, inside dead conch, $0.5 \mathrm{~m}$, leg. L. Torati, 06.08.2008, OUMNH.ZC.2008-14-053; 3 spec., Isla Colón, Puss Head Point, $09^{\circ} 21.802^{\prime} \mathrm{N} 082^{\circ} 14.333^{\prime} \mathrm{W}$, in coral rubble, 1-2 m, leg. S. De Grave, 08.08.2008, OUMNH.ZC.2008-14-052.

Remarks. Widespread in the western Atlantic, ranging from Bermuda across the Caribbean Sea and Gulf of Mexico to northeastern Brazil (Goy and Martin, 2013), usually in or under coral rubble, at depths less than $10 \mathrm{~m}$.

\section{Discussion}

A total of 151 species of caridean and 4 stenopodidean shrimp taxa have been recorded from the Caribbean side of Panama, including 20 species herein recorded for the first time. Numerically, the fauna is dominated by the Alpheidae (99 taxa in total) amounting to $63 \%$ of the fauna, with both Alpheus Fabricius, 1798 (34 taxa) and Synalpheus (44 taxa) well represented. This is not surprising, as the area has acted as one of the focal points of western Atlantic alpheid taxonomy in recent decades (e.g. Anker, 2008; 2010a; 2010b; 2011a; 2011b; 2012; Anker and Tóth, 
2008; Anker et al., 2007a; 2007b; 2008a; 2008b; Anker and Vera Caripe, 2016), as well as extensive biological studies on sponge dwelling species of Synalpheus (e.g. Duffy, 1992; 1993; 1996; Hultgren and Duffy, 2011). As is usual in the western Atlantic, the second most species rich family is the Palaemonidae, with 29 species in Caribbean Panama, i.e. 19\% of the total fauna, whilst all other families are represented only by a handful of species each.

A number of factors combine to make the current checklist far from complete. Firstly, the identity of a number of previously recorded taxa could not be confirmed during the present study. For example, Alpheus heterochaelis has been recorded a number of times in the past (Heck, 1977; 1979; Abele and Kim, 1989), whilst Processa sp. aff. hemphilli was recorded on a single occasion by Cubit and Williams (1983). Without a direct re-examination of the original material recorded under those names, it is not possible to speculate to which species these could refer to and for the time being these records must stand as is, although the presence of $A$. heterochaelis in Panama is extremely unlikely. Other such records are annotated in the list. Secondly, it is also clear that more as yet undescribed species are already known from Panama, for instance "Synalpheus brevicarpus A" and "S. guerini B" in Hultgren et al., 2014; “S. pandionis RED” in Morrison et al., 2004 (the latter also listed in Hultgren et al., 2010); and at least one unidentified, possibly undescribed species of Leptalpheus Williams, 1965 in Anker (2011), as well as a further, two undescribed species in the genera Alpheus and Odontozona Holthuis, 1946 which are currently being described by the second author. Additionally, a number of unresolved species complexes are known to have representatives in the Panamanian Caribbean fauna, such as the Alpheus normanni and Alpheus paracrinitus species complexes, each with several cryptic taxa (Williams et al., 2001; Anker, pers. obs.).

A biogeographical analysis of the western Atlantic shrimp fauna is rather hampered by the fact that the majority of species, especially in the numerically dominant Alpheidae, have only been described in the last two decades. Nevertheless a few relatively recent studies allow for a broad-brush comparison of species richness of the Caribbean Panamanian shrimp fauna. A total of 122 species of shallow water caridean and stenopodidean shrimps have been recorded from
Mexico (Felder et al., 2009; Santana-Moreno et al., 2013; Duarte et al., 2014), a much bigger country with the total Atlantic coastline approximately 2805 $\mathrm{km}$ long. Cuba, with a coastline of $3735 \mathrm{~km}$, has 106 species of caridean and stenopodidean shrimps (Martínez-Iglesias et al., 1996; Lalana and Ortiz, 2000; De Grave et al., 2017), although this number appears rather low and is likely due to insufficient sampling and taxonomic work. The Caribbean coastline of Panama is about $1288 \mathrm{~km}$ in length, which is roughly a third of those of the Atlantic coast of Mexico and Cuba. Yet it harbours proportionally a much higher number of species, with the total estimated number to be somewhat in excess of 154 species. Although species richness on this scale is largely a reflection of habitat heterogeneity, local sampling effort plays a significant role. It is interesting to note that the majority of recent records are from the immediate vicinity of the STRI Research Station in Bocas del Toro, a far smaller area than the total available coastal sampling area in Panama. In an interesting parallel, Cubagua Island (Venezuela) has been intensively sampled over a number of years and despite being only $22 \mathrm{~km}^{2}$ in area it harbours 46 species of Caridea and Stenopodidea (Hernández-Ávila et al., 2007). Without any doubts, additional sampling on the Caribbean coast of Panama, especially in waters deeper than $30 \mathrm{~m}$, as well as in the extensive San Blas Archipelago, will yield additional species of shrimps. However, it is already clear that Panama, with its heterogeneous Caribbean and Pacific coastlines, represents one of the major hotspots for marine biodiversity in the Americas and worldwide.

\section{ACKNOWLEDgementS}

SDG acknowledges Rachel Colin, Director of the Bocas del Toro Research Station (BRS) for the opportunity to participate in the Third Taxonomy Workshop (August 2005), funded by the Smithsonian Tropical Research Institute (STRI). Both authors acknowledge Rachel Colin for organising the August 2008 Caridean shrimp workshop at BRS, as well as the BRS based logistics experts and the collecting efforts of all the international participants. AA thanks the Programa de Capacitação Institucional (PCI) of the Museu Paraense Emílio Goeldi (MPEG) and Universidade Federal de Goiás (UFG) for providing funding to finalise this study. 


\section{References}

Abele, L.G. 1970. Semi-terrestrial shrimp (Merguia rhizophorae). Nature, 226: 661-662.

Abele, L.G. 1972a. Comparative habitat diversity and faunal relationships between the Pacific and Caribbean Panamanian decapod Crustacea: A preliminary report, with some remarks on the crustacean fauna of Panama. Bulletin of the Biological Society of Washington, 2: 125-138.

Abele, L.G. 1972b. A review of the genus Ambidexter (Crustacea: Decapoda; Processidae) in Panama. Bulletin of Marine Science, 22: $365-380$.

Abele, L.G. 1976. Comparative species composition and relative abundance of decapod crustaceans in marine habitats of Panamá. Marine Biology, 38: 263-278.

Abele, L.G. and Kim, W. 1989. The decapod crustaceans of the Panama Canal. Smithsonian Contributions to Zoology, 482: $1-50$.

Almeida, A.O. and Bezerra, L.E.A. 2011. Nikoides schmitti Manning \& Chace, 1971 (Caridea: Processidae) in the South Atlantic Ocean, with an updated list and key for processid shrimps of Brazil. Zootaxa, 2864: 24-42.

Almeida, A.O.; Boehs, G.; Araújo-Silva, C.L. and Bezerra, L.E.O. 2012. Shallow-water caridean shrimps from southern Bahia, Brazil, including the first record of Synalpheus ul (Ríos and Duffy, 2007) (Alpheidae) in the southwestern Atlantic Ocean. Zootaxa, 3347: 1-35.

Almeida, A.O.; Costa-Souza, A.C.; Cunha, A.M.; Santos, P.S.; Oliviera, M.V. and Soledade, G.O. 2013. Estuarine caridean shrimps (Crustacea: Decapoda) from Ilhéus, Bahia, Brazil: Updated checklist and a key for their identification. Check List, 9: 1396-1405.

Almeida, A.O.; Santos, P.S., Soledade, G.O., Santos, J.P. and Pérez, C.D. 2015. New invertebrate host records (Porifera and Cnidaria) for some caridean shrimps in estuaries of northeastern Brazil. Marine Biodiversity Records, 8: e38.

Almeida, A.O.; Terossi, M. and Mantelatto, F.L. 2014. Morphology and DNA analyses reveal a new cryptic snapping shrimp of the Alpheus heterochaelis Say, 1818 (Decapoda: Alpheidae) species complex from the western Atlantic. Zoosystema, 36: 53-71.

Anker, A. 2008. The shrimp genus Leptalpheus Williams, 1965 in the southwestern Caribbean Sea, with description of one new species from Panama (Crustacea, Decapoda, Alpheidae). Zoosystema, 30: 781-794.

Anker, A. 2010a. The shrimp genus Salmoneus Holthuis, 1955 (Crustacea, Decapoda, Alpheidae) in the tropical western Atlantic, with description of five new species. In: S. De Grave and C.H.J.M.Fransen (eds), Contributions to shrimp taxonomy. Zootaxa, 2372: 177-205.

Anker, A. 2010b. A new genus and three new species of alpheid shrimps (Crustacea, Decapoda, Caridea) from the tropical American coasts. Zootaxa, 2652: 47-63.

Anker, A. 2011a. Six new species and three new records of infaunal alpheid shrimps from the genera Leptalpheus Williams, 1965 and Fenneralpheus Felder and Manning, 1986 (Crustacea, Decapoda). Zootaxa, 3041: 1-38.

Anker, A. 2011 b. Two new species of Salmoneus Holthuis, 1955 with a deep dorsal depression on the carapace (Crustacea, Decapoda, Alpheidae). Zootaxa, 3041: 39-50.
Anker, A. 2012. Revision of the western Atlantic members of the Alpheus armillatus $\mathrm{H}$. Milne Edwards, 1837 species complex (Decapoda, Alpheidae), with descriptions of seven new species. Zootaxa, 3386: 1-109.

Anker, A.; Ahyong, S.; Noël, P. and Palmer, A.R. 2006. Morphological phylogeny of alpheid shrimps: parallel preadaptation and the origin of a key morphological innovation, the snapping claw. Evolution, 60: 2507-2528.

Anker, A. and Cox, D. 2011. A new species of the shrimp genus Lysmata Risso, 1816 (Crustacea, Decapoda) from Guam. Micronesica, 41: 197-214.

Anker, A. and De Grave, S. 2010. Holthuisaeus, a new genus for Periclimenes (Periclimenaeus) bermudensis Armstrong, 1940 (Decapoda, Palaemonidae, Pontoniinae). p. 115-131. In: C.H.J.M Fransen, S. De Grave and P.K.L. Ng (eds), Studies on Malacostraca: Lipke Bijdeley Holthuis Memorial Volume. Crustaceana Monographs, 14. Leiden, Brill.

Anker, A.; Hurt, C. and Knowlton, N. 2007a. Three transisthmian snapping shrimps (Crustacea: Decapoda: Alpheidae: Alpheus) associated with innkeeper worms (Echiura: Thalassematidae) in Panama. Zootaxa, 1626: 1-23.

Anker, A.; Hurt, C. and Knowlton, N. 2007b. Revision of the Alpheus nuttingi (Schmitt) complex (Crustacea: Decapoda: Alpheidae), with description of a new species from the tropical eastern Pacific. Zootaxa, 1577: 41-60.

Anker, A.; Hurt, C. and Knowlton, N. 2008a. Revision of the Alpheus cristulifrons species complex (Crustacea: Decapoda: Alpheidae), with description of a new species from the tropical eastern Atlantic. Journal of the Marine Biological Association of the United Kingdom, 88: 543-562.

Anker, A.; Hurt, C. and Knowlton, N. 2008b. Revision of the Alpheus formosus Gibbes, 1850 complex, with redescription of A. formosus and description of a new species from the tropical western Atlantic (Crustacea: Decapoda: Alpheidae). Zootaxa, 1707: 1-22.

Anker, A.; Hurt, C. and Knowlton, N. 2008c. Revision of the Alpheus websteri Kingsley, 1880 species complex (Crustacea: Decapoda: Alpheidae), with revalidation of $A$. arenensis (Chace, 1937). Zootaxa, 1694: 51-68.

Anker, A.; Hurt, C.; Jara, J.A. and Knowlton, N. 2008d. Revision of the Alpheus cylindricus Kingsley, 1878 species complex (Crustacea: Decapoda: Alpheidae), with revalidation of $A$. vanderbilti Boone, 1930. Zootaxa, 1943: 53-68.

Anker, A.; Hurt, C. and Knowlton, N. 2009. Description of cryptic taxa within the Alpheus bouvieri A. Milne Edwards, 1878 and A. hebes Kim and Abele, 1988 species complexes (Crustacea: Decapoda: Alpheidae). Zootaxa, 2153: 1-23.

Anker, A., Mendonça, J.B., Pachelle, P.P.G. and Tavares, M. 2013. New and additional records of Salmoneus Holthuis, 1955 (Decapoda, Caridea, Alpheidae) from Brazil, with a key to the southern Atlantic species. Papeis Avulsos de Zoologia, 53: $451-458$.

Anker, A. and Pachelle, P.P.G. 2013. Re-examination of the eastern Pacific and Atlantic material of Alpheus malleator Dana, 1852, with the description of Alpheus wonkimi sp. nov. (Crustacea, Decapoda, Alpheidae). Zootaxa, 3637: 412-431.

Anker, A. and Pachelle, P.P.G. 2014. Taxonomic notes on some Brazilian species of Synalpheus Spence Bate, 1888, with new records and description of a new species (Decapoda, Alpheidae). Zootaxa, 3815: 215-232. 
Anker, A.; Pachelle, P. P. G.; De Grave, S. and Hultgren, K. M. 2012. Taxonomic and biological notes on some Atlantic species of the shrimp genus Synalpheus Spence Bate, 1888 (Decapoda, Alpheidae). Zootaxa, 3598: 1-96.

Anker, A.; Tavares, M. and Mendonça, J.B. 2016. Alpheid shrimps (Decapoda: Caridea) of the Trindade and Martin Vaz Archipelago, off Brazil, with new records, description of a new species of Synalpheus and remarks on zoogeographical patterns in the oceanic islands of the tropical southern Atlantic. Zootaxa, 4138: 1-58.

Anker, A. and Tóth, E. 2008. A preliminary revision of the Synalpheus paraneptunus Coutière, 1909 species complex (Crustacea: Decapoda: Alpheidae). Zootaxa, 1915: 1-28.

Anker, A. and Vera Caripe, J. 2016. Leptalpheus pereirai sp. nov., a new alpheid shrimp from Panama and Venezuela. Zootaxa, 4127: 185-191.

Armstrong, J.C. 1941. The Caridea and Stomatopod of the second Templeton Crocker-American Museum expedition to the Pacific Ocean. American Museum Novitates, 1137: 1-14.

Ashelby, C.W.; Page, T.J.; De Grave, S.; Hughes, J.M. and Johnson, M.L. 2012. Regional scale speciation reveals multiple invasions of freshwater in Palaemoninae (Decapoda). Zoologica Scripta, 41: 293-306.

Baeza, J.A. 2008. Protandric simultaneous hermaphroditism in the shrimps Lysmata bahia and Lysmata intermedia. Invertebrate Biology, 127(2): 181-188.

Baeza, J.A. 2010. Molecular systematics of peppermint and cleaner shrimps: phylogeny and taxonomy of the genera Lysmata and Exhippolysmata (Crustacea: Caridea: Hippolytidae). Zoological Journal of the Linnean Society, 160: 254-265.

Baeza, J.A. and Anker, A. 2008. Lysmata hochi n. sp., a new hermaphroditic shrimp form the southwestern Caribbean Sea (Caridea: Hippolytidae). Journal of Crustacean Biology, 28: $148-155$.

Baeza, J.A.; Schubart, C.D.; Zillner, P.; Fuentes, S. and Bauer, R.T. 2009. Molecular phylogeny of shrimps from the genus Lysmata (Caridea: Hippolytidae): the evolutionary origins of protrandic simultaneous hermaphroditism and social monogamy. Biological Journal of the Linnean Society, 96: 415-424.

Barros-Alves, S.P.; Alves, D.F.R.; Silva, S.L.R.; Guimarães, C.R.P. and Hirose, G.L. 2015. New records of decapod crustaceans from the coast of Sergipe state, Brazil. Check List, 11: 1768.

Bezerra, L.E.A. and Almeida, A.O. 2008. Crustacea, Decapoda, Caridea, Alpheidae, Alpheus simus Guérin-Méneville, 1856: Further report from Brazilian waters. Check List, 4: 57-61.

Birkeland, C.; Reimer, A.A. and Young, J.R. 1976. Survey of marine communities in Panama and experiments with oil. Report EPA-600/3-76-028. Narrangasett, Environmental Research Laboratory.

Bracken-Grissom, H.D. and Felder, D.L. 2014. Provisional revision of American snapping shrimp allied to Alpheus floridanus Kingsley, 1878 (Crustacea: Decapoda: Alpheidae) with notes on A. floridanus africanus. Zootaxa, 3895: 451-491.

Brinkmann, B.W. and Fransen, C.H.J.M. 2016. Identification of a new stony coral host for the anemone shrimp Periclimenes rathbunae Schmitt, 1924 with notes on the host-use pattern. Contributions to Zoology, 85: 437-456.
Bruce, A.J. 2007. The resurrection of the pontoniine genus Urocaris Stimpson, 1860, (Crustacea: Decapoda: Palaemonidae). Zootaxa, 1632: 61-67.

Chace, F.A.Jr. 1972. The shrimps of the Smithsonian-Bredin Caribbean expeditions with a summary of the West Indian shallow-water species (Crustacea: Decapoda: Natantia). Smithsonian Contributions to Zoology, 98: 1-179.

Collin, R. 2005. Ecological monitoring and biodiversity surveys at the Smithsonian Tropical Research Institute's Bocas del Toro Research Station. Caribbean Journal of Science, 41: 367-373

Coutière, H. 1909. The American species of snapping shrimps of the genus Synalpheus. Proceedings of the United States National Museum, 36: 1-93.

Criales, M.M. 1980. Commensal caridean shrimps of Octocorallia and Antipatharia in Curaçao and Bonaire. Studies on the fauna of Curaçao and other Caribbean Islands, 188: 68-85.

Criales, M.M. 1992. Redescription of the hippolytid shrimp Trachycaris rugosa (Bate) (Crustacea: Decapoda: Caridea) from the western Atlantic, with notes on sexual dimorphism. Proceedings of the Biological Society of Washington, 105: 562570.

Criales, M.M. 1997. Microprosthema granatense, new species, from the southern Caribbean, with a key to shrimps of the genus Microprosthema from the western Atlantic and a new record of Odontozona libertae (Decapoda: Stenopodidea). Journal of Crustacean Biology, 17: 538-545.

Cubit, J. and Williams, S. 1983. The invertebrates of Galeta Reef (Caribbean Panama): A species list and bibliography. Atoll Research Bulletin, 269: 1-45.

De Grave, S. 2007. A new species of Pseudocoutierea Holthuis from the Caribbean coast of Panama (Crustacea, Decapoda, Palaemonidae), with a key to the genus. Zootaxa, 1397: 29-37.

De Grave, S. 2009. A further sponge-dwelling species of the Periclimenes iridescens complex from the western Atlantic (Decapoda, Caridea, Palaemonidae). Crustaceana, 82: 829836.

De Grave, S. and Anker, A. 2009. A new species of Periclimenes Costa from Utila, Honduras (Crustacea, Decapoda, Pontoniinae). Annalen des Naturhistorischen Museums in Wien, 110B: 139-148.

De Grave, S.; Anker, A.; Pindar, C.; Sandell, J. and Johnson, M.L. 2017. Eleven new records of caridean shrimps from Cuban waters (Decapoda, Caridea). Crustaceana, 90: 617-624.

De Grave, S. and Felder, D.L. 2012. The genus Processa in the vicinity of Carrie Bow Cay (Belize) with description of a new species (Crustacea: Decapoda: Processidae). Zootaxa, 3436: 41-50.

De Grave, S. and Fransen, C.H.J.M. 2011. Carideorum Catalogus: The recent species of the dendrobranchiate, stenopodidean, procarididean and caridean shrimps (Crustacea: Decapoda). Zoologische Mededelingen, 85: 195-589.

De Grave, S.; Fransen, C.H.J.M. and Page, T.J. 2015. Let's be pals again: major systematic changes in Palaemonidae (Crustacea: Decapoda). PeerJ, 3: e1167.

De Grave, S.; Li, C.P.; Tsang, L.M.; Chu, K.H. and Chan, T.Y. 2014. Unweaving hippolytoid systematics (Crustacea, Decapoda, Hippolytidae): resurrection of several families. Zoologica Scripta, 43: 496-507. 
Duarte, J.; Hermoso-Salazar, M.; Anker, A. and Simões, N. 2014. New records of alpheid shrimps (Crustacea: Decapoda: Alpheidae) from the southern Gulf of Mexico. Marine Biodiversity Records, 7: e110.

d'Udekem d'Acoz, C. 2007. New records of Atlantic Hippolyte, with the description of two new species, and a key to all Atlantic and Mediterranean species (Crustacea, Decapoda, Caridea). Zoosystema, 29: 183-207.

Duffy, J.E. 1992. Host use patterns and demography in a guild of tropical sponge-dwelling shrimps. Marine Ecology Progress Series, 90: 127-138.

Duffy, J.E. 1993. Genetic population structure in two tropical sponge-dwelling shrimps that differ in dispersal potential. Marine Biology, 116: 459-470.

Duffy, J.E. 1996. Species boundaries, specialization, and the radiation of sponge-dwelling alpheid shrimp. Biological Journal of the Linnean Society, 58: 307-324.

Duffy, J.E. 1998. On the frequency of eusociality in snapping shrimps (Decapoda: Alpheidae), with description of a second eusocial species. Bulletin of Marine Science, 63: 387-400.

Duffy, J.E. 2003. The ecology and evolution of eusociality in sponge-dwelling shrimp. p. 217-252. In: T. Kikuchi (ed), Genes, behavior, and evolution in social insects. Sapporo, University of Hokkaido Press.

Felder, D.L.; Alvarez, F.; Goy, J.W. and Lemaitre, R. 2009. Decapoda (Crustacea) of the Gulf of Mexico, with comments on the Amphionidacea. p. 1019-1104. In: D.L. Felder and D.K. Camp (eds), Gulf of Mexico. Origin, Waters and Biota. College Station, Texas A\&M University Press.

Ferreira, R.S.; Vieira, R.R.R. and D'Incao, F. 2010. The marine and estuarine shrimps of the Palaemoninae (Crustacea: Decapoda: Caridea) from Brazil. Zootaxa, 2606: 1-24.

Fiedler, G.C.; Rhyne, A.L.; Segawa, R.; Aotsuka, T. and Schizas, N.V. 2010. The evolution of euhermaphroditism in caridean shrimps: a molecular perspective of sexual systems and systematics. BMC Evolutionary Biology, 10: e297.

Fransen, C.H.J.M. 2002. Taxonomy, phylogeny, historical biogeography, and historical ecology of the genus Pontonia Latreille (Crustacea: Decapoda: Caridea: Palaemonidae). Zoologische Verhandelingen, 336: 1-433.

Fransen, C.H.J.M. and Almeida, A.O. 2009. Neopontonides brucei, a new pontoniine shrimp species from Brazilian waters (Decapoda, Palaemonidae). Crustaceana, 82: 837-846.

Gilchrist, S.L.; Scotto, L.E. and Gore, R.H. 1983. Early zoeal stages of the semiterrestrial shrimp Merguia rhizophorae (Rathbun, 1900) cultured under laboratory conditions (Decapoda, Natantia, Hippolytidae) with a discussion of characters in the larval genus Eretmocaris. Crustaceana, 45: 238-259.

Giribet, G. and Lemer, S. 2014. On the occurrence of Tuleariocaris neglecta Chace, 1969 (Decapoda, Palaemonidae, Pontoniinae) on Echinometra lucunter (Linnaeus, 1758) (Echinodermata, Echinoidea, Echinometridae) in the Archipelago of Bocas del Toro, Panama. Crustaceana, 87: 634-638.

Goy, J.W. and Martin, J.W. 2013. Redescription of Microprosthema semilaeve (von Martens, 1872) (Decapoda: Stenopodidae: Spongicolidae) and description of a new species of Microprosthema from Dry Tortugas, Florida. Zootaxa, 3630: 467-488.
Heard, R.W. and Spotte, S. 1997. Pontoniine shrimps (Decapoda: Caridea: Palaemonidae) of the northwest Atlantic. V. Periclimenes mclellandi, a new species, a gorgonian associate from Pine Cay, Turks and Caicos Islands, British West Indies. Proceedings of the Biological Society of Washington, 110: 39-48.

Heck, K.L.Jr. 1977. Comparative species richness, composition and abundance of invertebrates in Caribbean seagrass (Thalassa testudinum) meadows (Panamá). Marine Biology, 41: 335-348.

Heck, K.L.Jr. 1979. Some determinants of the composition and abundance of motile macroinvertebrate species in tropical and temperate turtlegrass (Thalassia testudinum) meadows. Journal of Biogeography, 6: 183-200.

Heck, K.L.Jr. and Weinstein, M.P. 1989. Feeding habits of juvenile reef fishes associated with Panamanian seagrass meadows. Bulletin of Marine Science, 45: 629-636.

Heck, K.L.Jr. and Wetstone, G.S. 1977. Habitat complexity and invertebrate species richness and abundance in tropical seagrass meadows. Journal of Biogeography, 4: 135-142.

Hernáez, P.; Martínez-Guerrero, B.; Anker, A. and Wehrtmann, I.S. 2010. Fecundity and effects of bopyrid infestation on egg production in the Caribbean sponge-dwelling snapping shrimp Synalpheus yano (Decapoda: Alpheidae). Journal of the Marine Biological Association of the United Kingdom, 90: 691-698.

Hernández-Ávila, I.; Gómez, A.; Lira, C. and Galindo, L. 2007. Benthic decapod crustaceans (Crustacea: Decapoda) of Cubagua Island, Venezuela. Zootaxa, 1557: 33-45.

Holthuis, L.B. 1951. A general revision of the Palaemonidae (Crustacea Decapoda Natantia) of the Americas. I. The subfamilies Euryrhynchidae and Pontoniinae. Occasional Papers of the Allan Hancock Foundation, 11: 1-332.

Holthuis, L.B. 1952. A general revision of the Palaemonidae (Crustacea Decapoda Natantia) of the Americas. II. The subfamily Palaemoninae. Occasional Papers of the Allan Hancock Foundation, 12: 1-396.

Hultgren, K.M. 2014. Variable effects of symbiotic snapping shrimps on their sponge hosts. Marine Biology, 161: 12171227.

Hultgren, K.M. and Brandt, A. 2015. Taxonomy and phylogenetics of the Synalpheus paraneptunus-species-complex (Decapoda: Alpheidae) with a description of two new species. Journal of Crustacean Biology, 35: 547-558.

Hultgren, K.M. and Duffy, J.E. 2011. Multi-locus phylogeny of sponge-dwelling snapping shrimp (Caridea: Alpheidae: Synalpheus) supports morphology-based species concepts. Journal of Crustacean Biology, 31: 352-360.

Hultgren, K.M.; Hurt, C. and Anker, A. 2014. Phylogenetic relationships within the snapping shrimp genus Synalpheus (Decapoda: Alpheidae). Molecular Phylogenetics and Evolution, 77: 116-125.

Hultgren, K.M.; MacDonald, K.S.II. and Duffy, J.E. 2010. Spongedwelling snapping shrimps of Curaçao, with descriptions of three new species. Zootaxa, 2372: 221-262.

Hurt, C.; Anker, A. and Knowlton, N. 2009. A multilocus test of simultaneous divergence across the Isthmus of Panama using snapping shrimp in the genus Alpheus. Evolution, 63: 514-530.

Hurt, C.; Silliman, K.; Anker, A. and Knowlton, N. 2013. Ecological speciation in anemone-associated snapping shrimps (Alpheus armatus species complex). Molecular Ecology, 22: 4532-4548. 
Kingsley, J.S. 1879. List of the North American Crustacea belonging to the suborder Caridea. Bulletin of the Essex Institute, 10(for 1878): 53-71.

Knowlton, N. and Keller, B.D. 1983. A new, sibling species of snapping shrimp associated with the Caribbean sea anemone Bartholomea annulata. Bulletin of Marine Science, 33: 353-362.

Knowlton, N. and Keller, B.D. 1985. Two more sibling species of alpheid shrimps associated with the Caribbean sea anemones Bartholomea annulata and Heteractis lucida. Bulletin of Marine Science, 37: 893-904.

Knowlton, N. and Mills, D.E.K. 1992. The systematic importance of color and color pattern: evidence for complexes of sibling species of snapping shrimp (Caridea: Alpheidae: Alpheus) from the Caribbean and Pacific coasts of Panama. Proceedings of the San Diego Society of Natural History, 18: 1-5.

Knowlton, N. and Weight, L.A. 1998. New dates and new rates for divergence across the Isthmus of Panama. Proceedings of the Royal Society of London B, 265: 2257-2263.

Knowlton, N.; Weight, L.A.; Solorzano, L.A.; Mills, D.E.K. and Bermingham, E. 1993. Divergence in proteins, mitochondrial DNA, and reproductive compatibility across the Isthmus of Panama. Science, 260: 1629-1632.

Lalana, R. and Ortiz, M. 2000. Lista actualizada de los crustaceos decapodos de Cuba. Revista Investigaciones Marinas, 21:33-44.

Macdonald, K.S.III and Duffy, J.E. 2006. Two new species of sponge-dwelling snapping shrimp from the Belizean Barrier Reef, with a synopsis of the Synalpheus brooksi species complex. American Museum Novitates, 3543: 1-22.

MacDonald, K.S. III; Hultgren, K. and Duffy, J.E. 2009. The sponge-dwelling snapping shrimps (Crustacea, Decapoda, Alpheidae, Synalpheus) of Discovery Bay, Jamaica, with descriptions of four new species. Zootaxa, 2199: 1-57.

Manning, R.B. and Chace, F.A.Jr. 1990. Decapod and stomatopod Crustacea from Ascension Island, South Atlantic Ocean. Smithsonian Contributions to Zoology, 503: 1-91.

Martínez-Iglesias, J.C.; Carvacho, A. and Ríos, R. 1996. Catálogo de los carídeos marinos (Crustacea, Decapoda, Caridea) de las aguas someras de Cuba. Avicennia, 4/5: 27-40.

Mathews, L.M. and Anker, A. 2009. Molecular phylogeny reveals extensive ancient and ongoing radiations in a snapping shrimp species complex (Crustacea, Alpheidae, Alpheus armillatus). Molecular Phylogenetics and Evolution, 50: 268-281.

McGrew, M. and Hultgren, K.M. 2011. Bopyrid parasite infestation affects activity levels and morphology of the eusocial snapping shrimp Synalpheus elizabethae. Marine Ecology Progress Series, 431: 195-204.

McKeon, C.S. and O'Donnell, J.L. 2015. Variation in partner benefits in a shrimp-sea anemone symbiosis. PeerJ, 3: e1409.

Morrison, C.L.; Ríos, R. and Duffy, J.E. 2004. Phylogenetic evidence for an ancient rapid radiation of Caribbean sponge-dwelling snapping shrimps (Synalpheus). Molecular Phylogenetics and Evolution, 30: 563-581.

Pachelle, P.P G.; Anker, A.; Mendes, C.B. and Bezerra, L.E.A. 2016. Decapod crustaceans from the state of Ceará, northeastern Brazil: an updated checklist of marine and estuarine species, with 23 new records. Zootaxa, 4131: 1-63.

Pachelle, P.P.G.; Paiva, S.V., Oliveira Filho, R.R. and Anker, A. 2012. The ascidian-associated shrimp Ascidonia miserabilis
(Caridea: Palaemonidae): first record for Brazil and additional records for the Caribbean Sea. Marine Biodiversity Records, 5: e83.

Rebolledo, A.P.; Wehrtmann, I.S.; Felder, D.L. and Mantelatto, F.L. 2014. Embryo production in the sponge-dwelling snapping shrimp Synalpheus apioceros (Decapoda, Alpheidae) from Bocas del Toro, Panama. Zookeys, 457: 227-238.

Rhyne, A.L.; Calado, R. and dos Santos, A. 2012. Lysmatajundalini, a new peppermint shrimp (Decapoda, Caridea, Hippolytidae) from the Western Atlantic. Zootaxa, 3579: 71-79.

Rhyne, A.L. and Lin, J. 2006. A western Atlantic peppermint shrimp complex: Redescription of Lysmata wurdemanni, description of four new species, and remarks on Lysmata rathbunae (Crustacea: Decapoda: Hippolytidae). Bulletin of Marine Science, 79: 165-204.

Ríos, R. and Duffy, J.E. 1999. Description of Synalpheus williamsi, a new species of sponge-dwelling shrimp (Crustacea: Decapoda: Alpheidae), with remarks on its first larval stage. Proceedings of the Biological Society of Washington, 112: 541-552.

Ríos, R. and Duffy, J.E. 2007. A review of the sponge-dwelling snapping shrimp from Carrie Bow Cay, Belize, with description of Zuzalpheus, new genus, and six new species. Zootaxa, 160: 1-89.

Robertson, D.R.; Christy, J.H.; Collin, R.; Cooke, R.G.; D’Croz, L.; Kaufmann, K.W.; Heckadon-Moreno, S.; Maté, J.L.; O’Dea, A. and Torchin, M.E. 2009. The Smithsonian Tropical research Institute: Marine research, education and conservation. Smithsonian Contributions to Marine Science, 38: 73-93.

Santana-Moreno, L.D.; De Grave, S. and Simões, N. 2013. New records of caridean shrimps (Decapoda: Caridea) from shallow water along the northern Yucatan peninsula coasts of México. Nauplius, 21: 225-238.

Soledade, G.O. and Almeida, A.O. 2013. Snapping shrimps of the genus Alpheus Fabricius, 1798 from Brazil (Caridea: Alpheidae): updated checklist and key for identification. Nauplius, 21: 89-122.

Tavares, M.; Carvalho, L. and Mendonça, J.B. 2017. Towards a review of the decapod Crusacea from the remote oceanic archipelago of Trindade and Martin Vaz, south Atlantic Ocean: New records and notes on ecology and zoogeography. Papeis Avulsos de Zoologia, 57: 157-176.

Terossi, M. and Mantelatto, F.L. 2012. Morphological and genetic variability in Hippolyte obliquimanus Dana, 1852 (Decapoda, Caridea, Hippolytidae) from Brazil and the Caribbean Sea. Crustaceana, 85: 685-712.

Tóth, E. and Bauer, R.T. 2007. Gonopore sexing technique allows determination of sex ratios and helper composition in eusocial shrimps. Marine Biology, 151: 1875-1886.

Tóth, E. and Bauer, R.T. 2008. Synalpheus paraneptunus (Crustacea: Decapoda: Caridea) populations with intersex gonopores: a sexual enigma among sponge-dwelling snapping shrimps. Invertebrate Reproduction and Development, 51: 49-59.

Tóth, E. and Duffy, J.E. 2005. Coordinated group response to nest intruders in social shrimp. Biology Letters, 1: 49-52.

Vieira, R.R.R.; Ferreira, R.S. and D’Incao, F. 2012. Pontoniinae (Crustacea: Decapoda: Caridea) from Brazil with taxonomic key. Zootaxa, 3149: 1-38. 
Wehrtmann, I.S. and Albornoz, L. 2002. Evidence of different reproductive traits in the transisthmian sister species, Alpheus saxidomus and A. simus (Decapoda, Caridea, Alpheidae): description of the first postembryonic stage. Marine Biology, 140: 605-612.

Wicksten, M.K. 1989. Hippolyte zostericola (Crustacea: Decapoda) in the Eastern Pacific. Proceedings of the Biological Society of Washington, 102: 644-645.

Wicksten, M. K. and Cox, C. 2011. Invertebrates associated with gorgonians in the northern Gulf of Mexico. Marine Biodiversity Records, 4: e79.
Wicksten, M.K., Nuttall, M.F. and Hickerson, E. L. 2014. Crustaceans from antipatharians on banks of the northwestern Gulf of Mexico. Zookeys, 457: 45-54.

Williams, A.B. 1984. Shrimps, lobsters, and crabs of the Atlantic coast of the eastern United States, Maine to Florida. Washington D.C., Smithsonian Institution Press, 550p.

Williams, S.T.; Knowlton, N.; Weigt, L.A. and Jara, A. 2001. Evidence for three major clades within the snapping shrimp genus Alpheus inferred from nuclear and mitochondrial gene sequence data. Molecular Phylogenetics and Evolution, 20: $375-389$. 